\title{
1 The Early Jurassic palynostratigraphy of the Lusitanian Basin, western
}

\section{Portugal}

3

4 Vânia F. Correia ${ }^{\mathrm{a}, \mathrm{b} *}$, James B. Riding ${ }^{\mathrm{c}}$, Luís V. Duarte ${ }^{\mathrm{d}}$, Paulo Fernandes $^{\mathrm{a}}$, Zélia Pereira ${ }^{\mathrm{b}}$

$5{ }^{a}$ CIMA - Centro de Investigação Marinha e Ambiental, Universidade do Algarve,

6 Campus de Gambelas, 8005-139 Faro, Portugal

$7 \quad$ b LNEG, Rua da Amieira, 4465-965 S. Mamede de Infesta, Portugal

$8 \quad{ }^{c}$ British Geological Survey, Environmental Science Centre, Keyworth, Nottingham

$9 \quad$ NG12 5GG, UK

$10{ }^{d}$ MARE - Marine and Environmental Sciences Centre, Faculty of Sciences and

11 Technology, Department of Earth Sciences, University of Coimbra, Rua Sílvio Lima,

$12 \quad 3030-790$ Coimbra, Portugal

14 *Corresponding author: E-mail address: vania.correia@lneg.pt (V.F. Correia)

16 Abstract

17 A comprehensive investigation of the Early Jurassic stratigraphical palynology of the

18 Lusitanian Basin in western Portugal was undertaken, with most emphasis placed on

19 dinoflagellate cysts. A total of 214 samples, from an upper Sinemurian to upper

20 Toarcian composite section based on six successions, were examined. The Sinemurian

21 material examined was barren of dinoflagellate cysts, however the Pliensbachian and

22 Toarcian successions are characterised by relatively low diversities. Luehndea spinosa,

23 Mancodinium semitabulatum, Mendicodinium microscabratum, Nannoceratopsis

24 gracilis, Nannoceratopsis senex and Scriniocassis priscus were relatively common, and

25 are biostratigraphically significant. Luehndea spinosa dominates the lowermost 
Toarcian (Dactylioceras polymorphum ammonite Biozone), and is an index species. At the base of Hildaites levisoni ammonite Biozone, the effects of the Toarcian-Oceanic Anoxic Event (T-OAE) caused Luehndea spinosa to become extinct. At the same time, dinoflagellate cyst abundance and diversity markedly decreased. After the T-OAE, during the middle and late Toarcian, phytoplankton recovery was prolonged and slow in the Lusitanian Basin. The Luehndea spinosa and Mendicodinium microscabratum dinoflagellate cyst biozones were defined, both of which are subdivided into two dinoflagellate cyst subbiozones.

Keywords: biostratigraphy, palynomorphs, dinoflagellate cysts, Lower Jurassic, Lusitanian Basin, Portugal.

\section{Introduction}

The Lusitanian Basin of central western Portugal is an important Mesozoic depocentre, and the calcareous microfossil biostratigraphy of the Lower Jurassic succession has been well studied recently (e.g., Perilli and Duarte, 2006; Oliveira et al., 2007a; Pinto, 2008; Reggiani et al., 2010; Henriques and Canales, 2013; Mattioli et al., 2013; Cabral et al., 2014, 2015; Henriques et al., 2014; Ferreira et al., 2015; Rita et al., 2016). By contrast, the Jurassic palynology of this significant sedimentary basin has received relatively little attention. Previous studies on the Jurassic palynobiotas of the Lusitanian Basin are Davies (1985), Mohr and Schmidt (1988), van Erve and Mohr (1988), Smelror et al. (1991), Bucefalo Palliani and Riding (1999a; 2003), Barrón and Azerêdo (2003), Oliveira et al. (2007b), Barrón et al. (2013) and Correia et al. (2017a,b). Davies (1985) is a reconnaissance biostratigraphical study, and Oliveira et al. (2007b) and Barrón et al. (2013) are mainly on pollen and spores. Correia et al. 
51 (2017a,b) discussed the palynology of the uppermost Pliensbachian to middle Toarcian interval at Maria Pares, Peniche and Vale das Fontes.

The present contribution is a detailed study of the Lower Jurassic palynology of key Sinemurian, Pliensbachian and Toarcian reference sections in the Lusitanian Basin (e.g., Duarte, 2007; Duarte et al., 2014b), with emphasis on dinoflagellate cysts because they are of the greatest regional biostratigraphical significance (Riding and Thomas, 1992; Poulsen and Riding, 2003). Specifically, the main aims are to document the upper Sinemurian to upper Toarcian palynomorphs from São Pedro de Moel, Brenha, Peniche, Fonte Coberta, Maria Pares and Vale das Fontes (Fig. 1), and to erect a dinoflagellate cyst biozonation.

\section{Geological background}

The Lusitanian Basin is a marginal marine depocentre in central western Portugal, and is oriented NE-SW (Fig. 1). It is $300 \mathrm{~km}$ long and $150 \mathrm{~km}$ wide, with a maximum basin fill of $5 \mathrm{~km}$ (Kullberg et al., 2013). The origin and evolution of this sedimentary basin are related to the breakup of Pangaea and the opening of the North Atlantic Ocean. The fill is mainly Jurassic but ranges from Middle? -Upper Triassic to Upper Cretaceous, and comprises four first order sedimentary cycles (Wilson et al., 1989). A clear Atlantic influence is evident from the ammonite faunas throughout most of the Lower Jurassic succession of the Lusitanian Basin (Mouterde et al., 1979). However, mixed Boreal and Tethyan faunas in the upper Pliensbachian to Toarcian interval indicate intermittent communication between the two realms (Elmi et al., 1989; Terrinha et al., 2002).

The lithostratigraphy of the Lower Jurassic of the Lusitanian Basin is summarised in Fig. 2. During the Early Jurassic, marine carbonate ramps formed rapidly in the 
Lusitanian Basin (Soares et al., 1993; Azerêdo et al., 2003, 2014; Duarte, 2007). The upper Sinemurian, especially in the western area, at Figueira da Foz, Peniche and São Pedro de Moel, mainly comprises marl-limestone couplets with ammonite-bearing black shales of the Água de Madeiros Formation (Duarte et al., 2010, 2012). The type section is at São Pedro de Moel in the central western part of the basin (Fig 1; Duarte and Soares, 2002; Duarte et al., 2014a,b). The overlying Pliensbachian and Toarcian hemipelagic deposits are rich in benthic and nektonic faunas; these are the Vale das Fontes, Lemede, São Gião, base of Cabo Carvoeiro and Póvoa da Lomba formations (Fig. 2; e.g., Duarte and Soares, 2002; Duarte et al., 2001, 2010, 2014b; Duarte, 2007). The Vale das Fontes Formation is Pliensbachian in age, ranges from the Uptonia jamesoni to Amaltheus margaritatus ammonite biozones and is subdivided into three informal members, the last one particularly enriched in organic mater (e.g., Silva et al., 2015; Silva and Duarte, 2015; Fig. 2). The succeeding Lemede Formation is upper Pliensbachian to lowermost Toarcian and spans the upper Amaltheus margaritatus to the lower Dactylioceras polymorphum ammonite biozones. The Toarcian of the Lusitanian Basin largely comprises the São Gião Formation, that spans the Dactylioceras polymorphum to the lower Dumortieria meneghinni ammonite biozones, and is subdivided into five informal members (Fig. 2; Duarte and Soares, 2002; Duarte, 2007). The type section of the São Gião Formation is at Maria Pares in the northern part of the Lusitanian Basin (Fig. 1). This locality exposes a continuous ammonite-bearing upper Pliensbachian to Aalenian succession (Mouterde et al., 1964-65; Henriques, 1992, 1995).

At Peniche, in the southwest of the Lusitanian Basin, a thick succession of Pliensbachian limestone-marl alternations overlain by the Toarcian Cabo Carvoeiro Formation which comprises at the top ooidal limestone-siliciclastic interbeds (Wright 
and Wilson, 1984; Duarte, 1997; Duarte et al., 2017). The type sections of the Vale das Fontes and Lemede formations are at Peniche, and this succession was recently formalised as the Toarcian Global Stratotype Section and Point (GSSP) (Rocha et al., 2016).

\section{Material and methods}

In this work, 214 samples collected from six Lower Jurassic successions in the Lusitanian Basin were analysed, involving the lithostratigraphical units described above. The loclities are São Pedro de Moel, Brenha, Peniche, Fonte Coberta, Maria Pares and Vale das Fontes (Figs. 1-9; Correia et al., 2017a,b). Twelve samples (prefixed PM) were collected from the upper Sinemurian Polvoeira Member of the Água de Madeiros Formation at Polvoeira, which forms the lowest part of the São Pedro de Moel composite section (Fig. 3). Herein, we refer to this section as "São Pedro de Moel", although the succession studied corresponds to the Polvoeira section of Duarte et al. (2012, 2014a). At Brenha, 22 samples were taken from a Pliensbachian composite section. The lower part of this section comprises the Vale das Fontes Formation (samples prefixed Br), and the upper part is the Lemede Formation (samples prefixed BrLem). The succession between these two formations is not continuous (Figs 2, 4). These two lithostratigraphical units and the Cabo Carvoeiro Formation were also sampled at Peniche, where 72 samples (numbered P-34 to P38) were collected (Fig. 5; Correia et al., 2017b). At Fonte Coberta, in the Rabaçal area, five samples (prefixed FC) from the upper Pliensbachian Vale das Fontes and Lemede formations were collected (Fig. 6). The section at Maria Pares comprises the lower, middle and upper Toarcian São Gião and Póvoa da Lomba formations. Eighty-nine samples (numbered PZ1 to PZ89) were collected (Figs. 7-9; Correia et al., 2017a). The type section of the São 
126 Gião Formation is at Maria Pares, and the lower Toarcian was previously studied by

127 Correia et al. (2017a). The latter authors also examined 14 samples (numbered PVF1 to PVF14) from the lower Toarcian part of the São Gião Formation at Vale das Fontes

129 (Correia et al., 2017a, fig. 5).

The samples were all prepared using standard palynological techniques (Wood et al., 1996), but the organic residues were not oxidised. All the residues were sieved using a $15 \mu \mathrm{m}$ mesh. The palynomorph concentrates were stained with Safranin to enhance the visibility of morphological features. When possible, a minimum of 300 palynomorphs were counted for each sample. The samples, aqueous residues, microscope slides and figured specimens are all curated in the collections of the LNEG (Portuguese Geological Survey), São Mamede de Infesta, Portugal.

\section{Palynological results}

\subsection{Introduction}

In this section, new reports on the Lower Jurassic palynofloras of the five sections studied are described. The data from 14 samples from the São Gião Formation at Vale das Fontes section were included in Correia et al. (2017a). The data presented by Correia et al. $(2017 \mathrm{a}, \mathrm{b})$ on Maria Pares and Peniche are also considered here. Most emphasis is placed on the dinoflagellate cysts, due their biostratigraphical significance. Selected palynomorphs are figured in Figs. 10-12. The overall percentages of all taxa from each section are depicted in supplementary Tables $1-5$, and the relative abundances of the six main palynomorph groups are plotted in supplementary Figures 1-5. The palynomorph taxa that were recorded herein, or mentioned in the text, are listed in the Appendix. 


\subsection{São Pedro de Moel}

Twelve samples, PM1 to PM12, were studied from the upper Sinemurian

Polvoeira Member of the Água de Madeiros Formation at São Pedro de Moel area.

These horizons span the Oxynoticeras oxynotum and Echioceras raricostatum ammonite biozones (Figs. 2, 3). All the 12 samples proved productive, but the palynomorphs were generally poorly preserved and no dinoflagellate cysts were observed. The assemblages are low in diversity and are dominated (normally $>95 \%$ ) by the gymnosperm pollen Classopollis classoides (Fig. 12/6). The prasinophyte genus Tasmanites (Fig. 12/4) is present throughout, reaching 19\% of the palynoflora in PM12. Other palynomorphs are present in low abundances and include acritarchs (Micrhystridium spp.), foraminiferal test linings, pollen (Alisporites spp. and Cerebropollenites macroverrucosus) and spores (Cyathidites spp. and Kraeuselisporites reissingeri) (supplementary Fig. 1; supplementary Table 1).

\subsection{Brenha}

The Lower Jurassic composite section at Brenha spans the Pliensbachian, and all five ammonite biozones are represented (Fig. 4). Twenty two samples (Br 1-20 and BrLem 1 and 2) were collected, and all except Br6 proved to be palynologically productive. The palynomorph assemblages are moderately well preserved, and exhibit higher diversites than the Sinemurian of São Pedro de Moel (supplementary Tables 1, 2).

Three dinoflagellate cyst species were encountered in the upper Pliensbachian; these are Mancodinium semitabulatum, Nannoceratopsis gracilis and Nannoceratopsis senex (Figs. 4, 10, 11). These species are present in both the Amaltheus margaritatus and the Emaciaticeras emaciatum ammonite biozones, corresponding to the MLOF 
member of the Vale das Fontes Formation, and the middle part of the Lemede Formation. Luehndea spinosa was not found in this succession. Dinoflagellate cysts in samples $\mathrm{Br} 14$ to $\mathrm{Br} 20$, within the Amaltheus margaritatus ammonite Biozone, are present in very low proportions, dominantly less than $1 \%$ of the palynoflora. However, the relative proportions of dinoflagellate cysts increased markedly in the Lemede Formation (Emaciaticeras emaciatum ammonite Biozone). All three species are present in significant numbers in samples BrLem1 and BrLem2; they represent $22.5 \%$ of the overall palynoflora in the latter sample (supplementary Table 2).

Other marine palynomorphs present at Brenha comprise foraminiferal test linings, Halosphaeropsis liassica, indeterminate acritarchs and prasinophytes, Micrhystridium spp., and Tasmanites spp. Foraminiferal test linings were only present in the upper Pliensbachian succession. However overall, these miscellaneous marine palynomorphs, like the dinoflagellate cysts, are most common in the Emaciaticeras emaciatum ammonite Biozone. Clearly, samples BrLem1 and BrLem2 exhibit the greatest marine influence in this succession (supplementary Fig. 2; supplementary Table 2).

The pollen grain Classopollis classoides is the most abundant palynomorph species throughout, with relative abundances between $27.0 \%$ and $94.5 \%$. The bisaccate pollen genus Alisporites is also sporadically common, and other pollen present, normally in low proportions, are Araucariacites australis, Cerebropollenites macroverrucosus and Spheripollenites spp. The spores Cyathidites spp. and Kraeuselisporites reissingeri, together with indeterminate forms, are present throughout the succession. Leptolepidites rotundus and Lycopodiacidites rugulatus were sporadically identified in the upper Pliensbachian samples (supplementary Table 2). 


\subsection{The Pliensbachian and lower Toarcian succession at Peniche}

A total of 72 samples were collected from the lower Pliensbachian to lower Toarcian (Tragophylloceras ibex to Hildaites levisoni ammonite biozones) succession at Peniche (Fig. 1; supplementary Table 3). These were studied herein, and by Correia et al. (2017b). Twenty-seven samples, P-34 to P-8, were collected from the Pliensbachian Vale das Fontes and Lemede formations (Figs. 2, 5). Correia et al. (2017b) reported on 45 samples (P-7 to P38), from the overlying uppermost Lemede Formation and the lowermost Cabo Carvoeiro Formation (uppermost Pliensbachian-lower Toarcian). Fourteen samples from the upper Pliensbachian and lower Toarcian succession proved entirely devoid of palynomorphs (supplementary Table 3). The remaining 58 samples yielded reasonably abundant palynomorph assemblages which are moderately well preserved.

Eight forms of dinoflagellate cyst were recognised. The most stratigraphically extensive species are Luehndea spinosa, Mancodinium semitabulatum, Nannoceratopsis gracilis and Nannoceratopsis senex. Mendicodiniuim microscabratum, Nannoceratopsis ambonis, Nannoceratopsis sp. and Scriniocassis weberi occurred sporadically, and in low numbers (Figs. 5, 10, 11; supplementary Table 3). In the Pliensbachian part of this succession, between the upper Prodactylioceras davoei to lowermost Emaciaticeras emaciatum ammonite biozones (samples P-29 to P-13,) dinoflagellate cysts are especially sparse and comprise only Luehndea spinosa, Mancodinium semitabulatum, Nannoceratopsis senex and Nannoceratopsis sp. (supplementary Fig. 3). The latter form represents a single specimen found in sample P-20 in the Amaltheus margaritatus ammonite Biozone. It has two subequal antapical horns, and does not precisely conform to any of the formalised species of this genus (Fig. 10/4). The lowermost occurrence of Mancodinium semitabulatum is at the top of Prodactylioceras davoei ammonite 
226 Biozone, in sample P-29, where it is relatively sparse. Luehndea spinosa is only present, 227 again in very low proportions, in samples P-26 and P-23 from the Amaltheus margaritatus ammonite Biozone. Stratigraphically above these records, Mancodinium semitabulatum, reappeared in the Emaciaticeras emaciatum ammonite Biozone (samples P-12 to P-10) in significantly greater proportions, up to $5.9 \%$ of the overall palynoflora. A similar occurrence pattern was exhibited by Nannoceratopsis senex. This species is rare in the Amaltheus margaritatus ammonite Biozone (samples P-28 to P21), and became more frequent in the Emaciaticeras emaciatum ammonite Biozone (samples P-12 and P-10). Therefore, the consistent occurrence of relatively common Mancodinium semitabulatum is in sample P-12. From this horizon in the Emaciaticeras emaciatum ammonite Biozone to the top of Dactylioceras polymorphum ammonite Biozone (sample P14; see Table 3), dinoflagellate cysts are abundant to common. Luehndea spinosa has two prominent acmes in the Emaciaticeras emaciatum and Dactylioceras polymorphum ammonite biozones (Correia et al., 2017b). Mancodinium semitabulatum is also common at the Emaciaticeras emaciatum-Dactylioceras polymorphum ammonite Biozone transition. Nannoceratopsis spp. were also prominent in sample P6 in the Dactylioceras polymorphum ammonite Biozone (supplementary Table 3). In the Lusitanian Basin, the beginning of the Toarcian Oceanic Anoxic Event (T-OAE) corresponds to the base of Hildaites levisoni ammonite Biozone (Hesselbo et al., 2007; Suan et al., 2008; Pittet et al., 2014; Correia et al., 2017a,b). This anoxic event (samples P15 to P24) badly affected the dinoflagellates due to profound benthic palaeoenvironmental stress (Correia et al., 2017b), and the assemblages had not recovered at the level of sample P38 in the Hildaites levisoni ammonite Biozone. The 
only survivors were sparse and sporadic Mancodinium semitabulatum and

Mendicodiniuim microscabratum (supplementary Table 3).

Miscellaneous marine palynomorphs were recorded throughout this succession.

They include acritarchs (indeterminate forms, Micrhystridium spp. and Polygonium jurassicum), foraminiferal test linings and prasinophytes (Cymatiosphaera sp. cf. C. pachytheca, Halosphaeropsis liassica, indeterminate forms and Tasmanites spp.).

Generally, these occurrences are in small proportions $(<1-2 \%$ of the palynoflora); foraminiferal test linings and Tasmanites spp are the most consistently observed (supplementary Fig. 3; supplementary Table 3). Foraminiferal test linings and Tasmanites spp. are sporadically relatively frequent between samples P-32 and P-26 (Tragophylloceras ibex to Amaltheus margaritatus ammonite biozones), and in the productive part of the Emaciaticeras emaciatum ammonite Biozone (samples P-12 to P10) (supplementary Table 3). The interval between samples P-25 and P-7 is relatively sparse in miscellaneous microplankton. Unlike dinoflagellate cysts, miscellaneous microplankton are present in relatively moderate proportons in the T-OAE interval (samples P15 to P24). Foraminiferal test linings are most prominent in this interval, and these dominate the palynobiotas above the T-OAE. In sample P36, these palynomorphs attain $71.9 \%$ of the assemblage (supplementary Table 3 ).

All the palynologically productive samples yielded terrestrially-derived palynomorphs in substantial proportions. The pollen grains Alisporites spp., Araucariacites australis, Cerebropollenites macroverrucosus, Classopollis classoides, Exesipollenites spp. and Spheripollenites spp. were recognised. Classopollis classoides is normally the most abundant palynomorph below sample P5 in the lowermost Toarcian, with overall percentages up to $97.4 \%$ in sample P-21. The bisaccate genus Alisporites was relatively frequent in the upper Pliensbachian. Most pollen declined at 
the T-OAE, however Exesipollenites spp. and Spheripollenites spp. are more frequent in this succession than below the T-OAE (supplementary Table 3). Pteridophyte spores were recorded in relatively low numbers throughout the succession. Cyathidites spp., indeterminate spores, Kraeuselisporites reissingeri and Leptolepidites spp. were the most consistently present. Other forms were encountered rarely; these include Concavisporites granulosus, Ischyosporites vaerigatus, Lycopodiacidites rugulatus and Plicifera delicata. Unlike most pollen taxa, spores generally were slightly more frequent during the T-OAE and above it (supplementary Fig. 3; supplementary Table 3).

\subsection{Fonte Coberta}

Five palynologically productive samples, FC1 to FC5, were collected from the upper Pliensbachian section at Fonte Coberta, near Rabaçal in the northern part of the Lusitanian Basin (Fig. 1, supplementary Table 4). The samples are from the top of the Vale das Fontes and Lemede formations, and span the Amaltheus margaritatus and Emaciaticeras emaciatum ammonite biozones (Figs. 2, 6).

The palynomorphs from Fonte Coberta are of low diversity and are moderately well preserved. Three dinoflagellate cysts, Luehndea spinosa, Mancodinium semitabulatum and Nannoceratopsis senex, were identified (Figs. 6, 10). The latter occurred in low numbers throughout the succession. By contrast, Mancodinium semitabulatum and Luehndea spinosa are confined to the Emaciaticeras emaciatum ammonite Biozone. The former was recorded in low proportions, but Luehndea spinosa was the most abundant palynomorph in samples FC3 (85.2\%) and FC5 (62.4\%) (supplementary Fig. 4; supplementary Table 4). This abundance of Luehndea spinosa at the Pliensbachian-Toarcian transition in the Lusitanian Basin was also observed by Correia et al. (2017a,b). 

the samples except FC4. These comprise acritarchs (indeterminate forms and Micrhystridium spp.), foraminiferal test linings and prasinophytes (indeterminate forms and Tasmanites spp.). The most significant occurrence is the relatively high levels of foraminiferal test linings in the Emaciaticeras emaciatum ammonite Biozone (supplementary Table 4).

In samples FC1, FC2 and FC4, by the most abundant palynomorph was the pollen grain Classopollis classoides; it is also abundant in FC5. It represented $>90 \%$ of the palynoflora in samples FC1 and FC4. There is an apparently inverse relationship between the abundances of Classopollis classoides and the dinoflagellate cyst Luehndea spinosa (supplementary Fig. 4; supplementary Table 4). Other pollen grains present in low proportions are Alisporites spp., Araucariacites australis and Cerebropollenites macroverrucosus. The spores recorded were Cyathidites spp., indeterminate forms and Kraeuselisporites reissingeri (supplementary Table 4).

\section{6. $\quad$ The lower to upper Toarcian succession at Maria Pares} Eighty nine samples were taken from the lower, middle and upper Toarcian at

317 Maria Pares, in the Rabaçal area of the eastern sector of the basin (Fig. 1, supplementary Table 5). This material is from the São Gião and Póvoa da Lomba formations, and the samples span the Dactylioceras polymorphum to the Pleydellia aalensis ammonite biozones (Figs. 2, 7-9). This material was studied herein, and also by Correia et al. (2017a) who reported on the lowermost 54 samples PZ-1 to PZ54 from the São Gião Formation (lower and middle Toarcian). The overlying 35 samples PZ55 to PZ89, from the middle and upper Toarcian were part of this study only. All but five of the samples proved palynologically productive, with moderately well presered palynobiotas. Three 
samples from the upper Toarcian Pleydellia aalensis ammonite Biozone proved entirely devoid of palynomorphs (supplementary Table 5).

Thirteen dinoflagellate cyst forms were identified. These are: Dapsilidinium? deflandrei; Luehndea spinosa; Mancodinium semitabulatum; ?Maturodinium inornatum; Mendicodinium microscabratum; Mendicodinium spinosum subsp. spinosum; Mendicodinium sp.; Nannoceratopsis ambonis; Nannoceratopsis gracilis; Nannoceratopsis senex; Scriniocassis priscus; Sentusidinium sp.; and Valvaeodinium sp. (Figs. 10, 11; supplementary Table 5). As in other sections, the most consistently occurring dinoflagellate cyst throughout is Mancodinium semitabulatum, the range top of which is in the Dumortieria meneghinii ammonite Biozone. Luehndea spinosa is dominant in the upper part of the Dactylioceras polymorphum ammonite Biozone. Mancodinium semitabulatum is also common in this ammonite biozone and around the lower-middle Toarcian transition (samples PZ27 and PZ51; see supplementary Table 5). The range base of consistent Mendicodinium microscabratum and Scriniocassis priscus is PZ554 in the Hildoceras bifrons ammonite Biozone. The stratigraphically highest record of Scriniocassis priscus is in the Hammatoceras speciosum ammonite Biozone. The maximum abundance of Mendicodinium microscabratum is $27.3 \%$ in sample PZ56 in the Hildoceras bifrons ammonite Biozone, with the stratigraphically highest record in Hammatoceras speciosum ammonite Biozone. Nannoceratopsis spp. did not recover following the T-OAE, but Nannoceratopsis senex is sporadically present in the Dumortieria meneghinii and Pleydellia aalensis ammonite biozones. In the Pleydellia aalensis ammonite Biozone, Nannoceratopsis senex was the only dinoflagellate cyst species present, with $10.3 \%$ of the overall palynoflora in sample PZ88. Dapsilidinium? deflandrei, ?Maturodinium inornatum, Mendicodinium spinosum subsp. spinosum, Mendicodinium sp., Nannoceratopsis ambonis, Sentusidinium sp. and Valvaeodinium 
sp. were extremely rare (supplementary Table 5). For example, only one and two specimens each respectively of Dapsilidinium? deflandrei (samples PZ57) and ?Maturodinium inornatum (samples PZ58 and PZ77) were encountered (supplementary Table 5).

Other marine palynomorphs encountered throughout this succession were foraminiferal test linings, Halosphaeropsis liassica, indeterminate acritarchs and prasinophytes, Micrhystridium spp. and Tasmanites spp. These palynomorphs were dominated by acanthomorph acritarchs, foraminiferal test linings and prasinophytes. Indeterminate acritarchs and Micrhystridium spp. are normally most prevalent in the lower and lowermost middle Toarcian, and foraminiferal test linings and indeterminate prasinophytes are most abundant in the upper Toarcian samples (supplementary Fig. 5).

Clumps of Halosphaeropsis liassica increased their abundance from the Hildaites levisoni ammonite Biozone (sample PZ9, 89.7\%, see supplementary Table 5; supplementary Fig. 5).

All the palyniferous samples produced pollen-spore floras in significant numbers. The pollen comprises Alisporites spp., Araucariacites australis, Callialasporites dampieri, Callialasporites turbatus, Cerebropollenites macroverrucosus, Classopollis classoides, Classopollis sp., Cycadopites sp. Exesipollenites spp., Inaperturopollenites sp., indeterminate forms and Spheripollenites spp. The diversity is greatest in the uppermost middle and upper Toarcian, and the dominant and consistent elements are Alisporites spp., Araucariacites australis and Classopollis classoides (supplementary Table 5). The latter is present throughout, and is the most abundant species, reaching a maximum of $50 \%$ of the palynoflora in sample PZ85 (Dumortieria meneghinii ammonite Biozone). The range top of Araucariacites australis, and the inception of Callialasporites spp., are in the middle Toarcian 
375 (Brodiela gradata ammonite Biozone). The spores were relatively high in diversity, but only Cyathidites spp., indeterminate spores, Ischyosporites variegatus and Leptolepidites spp. were consistent and relatively frequent.

\section{Discussion of the Lower Jurassic palynofloras of the Lusitanian Basin}

\subsection{Introduction}

In this section, the palynological data outlined in section 4 are discussed and interpreted, primarily in terms of their biostratigraphical significance. A biostratigraphical scheme for the Pliensbachian and Toarcian of the Lusitanian Basin based on key dinoflagellate cysts bioevents is presented as Figure 13, and a formal biozonation is outlined in section 6 .

\subsection{Upper Sinemurian palynology}

The upper Sinemurian succession at São Pedro de Moel proved entirely devoid of dinoflagellate cysts, confirming the findings of Duarte et al. (2012) and Poças

Ribeiro et al. (2013). The late Sinemurian marker dinoflagellate cyst Liasidium variabile was not recovered. This distinctive species is characteristic of the upper Sinemurian of northwest Europe, and is a proven thermophilic taxon (Riding and Hubbard, 1999; Brittain et al., 2010; Riding et al., 2013). Liasidium variabile thrived, and Classopollis classoides was extremely abundant, during a brief palaeoenvironmental perturbation in the late Sinemurian ( 194 Ma) of northwest isotopically-light carbon, global warming and organic shale deposition (Riding et al., 2013). Organic-rich facies, resulting from anoxic/dysoxic intervals, occurred during the 

abundant in the upper Sinemurian of São Pedro de Moel, and this represents the acme for the entire sucesson examined (supplementary Tables 1-5). The absence of Liasidium variabile at São Pedro de Moel may indicate that this species had specific palaeoenvironmental preferences, and did not migrate south of $\sim 30^{\circ}$ latitude at this time 405 (Riding et al., 2013, fig. 1).

406

\subsection{Pliensbachian and Toarcian palynology}

The five Pliensbachian and Toarcian successions studied herein, and by Correia et al. (2017a,b), are Brenha, Peniche, Fonte Coberta, Maria Pares and Vale das Fontes (Figs. 1-9); all these sections produced dinoflagellate cyst assemblages. Fifteen forms were recorded; these are: Dapsilidinium? deflandrei; Luehndea spinosa; Mancodinium semitabulatum; ?Maturodinium inornatum; Mendicodinium microscabratum; ambonis; Nannoceratopsis gracilis; Nannoceratopsis senex; Nannoceratopsis sp.;

Scriniocassis priscus; Scriniocassis weberi; Sentusidinium sp.; and Valvaeodinium sp. (supplementary Tables 1-5).

Other aquatic palynomorphs observed comprise acanthomorph acritarchs, foraminiferal test linings and prasinophytes (supplementary Tables 1-5; Correia et al., 2017a,b). Pollen and spores are also present in relatively high relative proportions. The gymnospermous pollen species Classopollis classoides is the most abundant terrestrially-derived palynomorph in the Lower Jurassic of the Lusitanian Basin. Other pollen taxa present in significant numbers are Alisporites spp., Araucariacites australis and Cerebropollenites macroverrucosus. The spores Cyathidites spp., Ischyosporites 
variegatus, Leptolepidites spp. and Kraeuselisporites reissingeri were also frequently encountered throughout. The miscellaneous marine microplankton, pollen and spores are relatively conservative in their occurrences through this composite Sinemurian to Toarcian succession, and are consistent with an Early Jurassic age (Srivastava, 1987; 2011; Weiss, 1989; Ziaja, 2006; Quattrocchio et al., 2011; Bomfleur et al., 2014). These relative low diversity dinoflagellate cyst assemblages are broadly typical of upper Pliensbachian to Toarcian successions throughout Europe and adjacent areas (Riding, 1984a; Riding et al., 1991; 1999; Koppelhus and Nielsen, 1994; Bucefalo Palliani and Riding, 1997a,b; 1999a; 2000; 2003; Baranyi et al., 2016). Furthermore, the dinoflagellate cyst association reported herein is consistent with previous research on the Lower Jurassic palynology of the Lusitanian Basin (Davies, 1985; Oliveira et al., 2007b; Barrón et al., 2013). For example, Davies (1985), Oliveira et al. (2007a) and Barrón et al. (2013) also recorded Luehndea spinosa, Mancodinium semitabulatum, Mendicodinium sp., Nannoceratopsis senex, Nannoceratopsis gracilis, Nannoceratopsis sp. Scriniocassis weberi and Scriniocassis priscus from this area.

The dinoflagellate cyst diversity in the upper Pliensbachian of the Lusitanian Basin is relatively low, with only Luehndea spinosa, Mancodinium semitabulatum, Mendicodinium microscabratum, Nannoceratopsis senex, Nannoceratopsis gracilis and Nannoceratopsis sp. present. In terms of abundances, dinoflagellate cysts are relatively rare in the Amaltheus margaritatus ammonite Biozone, but increased markedly within the Emaciaticeras emaciatum ammonite Biozone (supplementary Tables 2, 3). Both abundances and diversity increased in the earliest Toarcian Dactylioceras polymorphum ammonite Biozone. Luehndea spinosa dominates the palynofloras at the PliensbachianToarcian transition (upper Emaciaticeras emaciatum and lower Dactylioceras polymorphum ammonite biozones), at Peniche, Fonte Coberta, Maria Pares and Vale 
das Fontes (Fig. 6; supplementary Tables 3-5; Correia et al., 2017a,b). For example,

450

451

452

453

454

455

456

457

458

459

460

461

462

463

464

465

466

467

468

469

470

471

472

473 this species attained a maximum of $96.2 \%$ of the overall palynoflora in sample P11 at Peniche (supplementary Table 3). At Peniche, Maria Pares and Vale das Fontes, the abundance curves of Luehndea spinosa in the Dactylioceras polymorphum ammonite Biozone exhibit a characteristic double peak signature (Correia et al., 2017a,b). These acmes may reflect pulses of an early Toarcian transgressive event prior to the start of the T-OAE in the lowermost Hildaites levisoni ammonite Biozone (Duarte et al., 2004, 2007; Pittet et al., 2014).

The Toarcian dinoflagellate cyst assemblages above the base of Hildaites levisoni ammonite Biozone are dominated by Mancodinium semitabulatum and Mendicodinium spp. During the Toarcian, Dapsilidinium? deflandrei, ?Maturodinium inornatum, Mendicodinium spinosum subsp. spinosum, Mendicodinium sp., Nannoceratopsis ambonis, Scriniocassis priscus, Scriniocassis weberi, Sentusidinium sp. and Valvaeodinium sp. had their inceptions (supplementary Tables 3, 5). Despite the somewhat moderate increase in diversity in the Toarcian, above the Dactylioceras polymorphum ammonite Biozone, overall dinoflagellate cyst abundances markedly reduced due to the palaeoenvironmental perturbations caused by the T-OAE and the recovery from this event (Correia et al., 2017a,b). Only Mancodinium semitabulatum is consistently relatively common. Mendicodinium microscabratum and Nannoceratopsis senex were only sporadically present in reasonable proportions, and other forms were extremely rare (supplementary Tables 3,5 ).

Hence the recovery of dinoflagellates after the T-OAE at Maria Pares and Peniche was extremely slow and somewhat indistinct (supplementary Tables 3, 5). A good example is the reappearance of Nannoceratopsis senex following the T-OAE. In northwest Europe, this species was typically suppressed only for part of the Harpoceras 
exaratum ammonite Subbiozone of the Harpoceras serpentinum ammonite Biozone in

475 the early Toarcian (Bucefalo Palliani and Riding, 2000, fig. 3; Bucefalo Palliani et al., 2002, figs. 3, 13). In northern Siberia, this species was apparently unaffected by the T-

OAE (Riding et al., 1999, fig. 11). By contrast, in the Lusitanian Basin,

Nannoceratopsis senex reappeared in the late Toarcian (Dumortieria meneghinnii ammonite Biozone, supplementary Table 5). This slow dinoflagellate recovery in southern Europe was also illustrated by Correia et al. (2017a, fig. 10). The apparently unaffected dinoflagellate cyst associations of the high northerly latitudes and a slow recovery in southern Europe, with an intermediate region (northwest Europe) intercalated between these, appears to be a coherent trend. Despite intense Early Toarcian anoxia in northwest Europe, the palaeoenvironment in Italy and Portugal was far slower to recovery (Bucefalo Palliani et al., 2002; van de Schootbrugge et al., 2005; Jenkyns et al., 2010; Correia et al., 2017a,b). This may have been linked to the reestablishment of marine circulation patterns at this time. following the T-OAE in the mid Toarcian to earliest Aalenian is a minor radiation of a plexus of small genera placed in the Family Heterocapsaceae and termed the 'Parvocysta complex’ (Riding, 1984a; Riding et al., 1991; 1999; Butler et al., 2005; Feist-Burkhardt and Pross, 2010). This association is absent throughout the Lusitanian Basin, where the only significant dinoflagellate cyst inceptions in the middle Toarcian are those of Mendicodinium microscabratum and Scriniocassis priscus (Fig. 13).

495 Furthermore, typical Tethyan species, such as Mendicodinium brunneum, hirsutum are also absent in central western Portugal (Bucefalo Palliani and Riding, 1997a, c; 1999a,b; 2003; Bucefalo Palliani et al., 1997a). 
500 5.4. Pliensbachian and Toarcian palynomorph biostratigraphy of the Lusitanian 501 Basin

502

503

504

505

506

507

508

509

510

511

512

513

514

515

516

517

518

519

520

521

522

In this subsection, the biostratigraphical significance of the principal palynomorphs, with the emphasis on dinoflagellate cyst taxa, are discussed.

Dapsilidinium? deflandrei was found in the Hildoceras bifrons ammonite Biozone at Maria Pares (supplementary Table 5). This species is very rare in the Middle Jurassic of northwest Europe (Valensi, 1947; Davey and Riley, 1978), and this is the first report from the Early Jurassic.

Luehndea spinosa ranges from the upper Pliensbachian to the lowermost Toarcian (Amaltheus margaritatus to Dactylioceras polymorphum ammonite biozones) in the Lusitanian Basin (Fig. 13). This range is consistent with the extent of this distinctive and widespread species in Europe and elsewhere (Morgenroth, 1970; Riding, 1987; Bucefalo Palliani and Riding, 1997a,b; 2000; 2003; Bucefalo Palliani et al., 1997b). The range base of Luehndea spinosa in the Lusitanian Basin is represented by sparse and sporadic occurrences close to the base of the Amaltheus margaritatus ammonite Biozone at Peniche (Fig. 5; supplementary Table 3). These occurrences of Luehndea spinosa in the Amaltheus margaritatus ammonite Biozone, together with Mancodinium semitabulatum, Nannoceratopsis gracilis and Nannoceratopsis senex, confirms the late Pliensbachian age of the uppermost MLOF member of the Vale das Fontes Formation. Luehndea spinosa was not recorded in the coeval strata at Brenha (Fig. 4), possibly because the Brenha section is more proximal than Peniche (Fig. 1). Luehndea cirilliae is present in the upper Pliensbachian and lower Toarcian of Hungary (Baldanza et al., 1995; Bucefalo Palliani et al., 1997b; Baranyi et al., 2016). This 
species was also reported in the Pliensbachian of Brenha by Bucefalo Palliani and Riding (2003), but this taxon was not found in this study, or by Correia et al. (2017a,b). Mancodinum semitabulatum (Fig. 11/9-12) is present in the PliensbachianToarcian successions at Brenha, Peniche, Fonte Coberta, Maria Pares and Vale das Fontes (supplementary Tables 2-5; Correia et al., 2017a). This species has a consistent range of late Pliensbachian to early Bajocian (Riding, 1984b; Feist Burkhardt and Wille 1992; Riding and Thomas 1992; Wiggan et al., 2017). The stratigraphically lowest record of Mancodinum semitabulatum in the Lusitanian Basin is at the top of Prodactylioceras davoei ammonite Biozone at Peniche (sample P-29, see Fig. 5; supplementary Table 3). At Brenha, Mancodinum semitabulatum was identified at the base of the Amaltheus margaritatus ammonite Biozone, in the MLOF member of the Vale das Fontes Formation (Fig. 4; supplementary Table 2). This species became much more common and consistent in the uppermost Pliensbachian and lowermost Toarcian (Emaciaticeras emaciatum and Dactylioceras polymorphum ammonite biozones) throughout the Lusitanian Basin (supplementary Tables 2, 3; Correia et al., 2017a,b). Mancodinum semitabulatum was significantly suppressed by the T-OAE, and is sparse for the remainder of the Toarcian in the Lusitanian Basin, between the Hildaites levisoni and the Dumortieria meneghinii ammonite biozones (Fig. 13; supplementary Table 5). Rare, questionable specimens of Maturodinium inornatum were observed in the middle and upper Toarcian at Maria Pares (supplementary Table 5). This species was previously believed to be confined to the upper Pliensbachian (Morgenroth, 1979; FeistBurkhardt and Wille, 1992).

At Peniche and Maria Pares, Mendicodinium microscabratum was recorded between the Hildaites levisoni and the Hammatoceras speciosum ammonite biozones (Fig. 13; supplementary Tables 3, 5). This is inconsistent with the range of 

polymorphum ammonite Biozone equivalent of central Italy reported by Bucefalo Palliani et al. (1997a). Thus, the records of Mendicodinium microscabratum in the middle and upper Toarcian in the Lusitanian Basin are the youngest known occurrences. The oldest occurrences of the genus Nannoceratopsis in the Lusitanian Basin are the records of Nannoceratopsis gracilis and Nannoceratopsis senex at the base of the Amaltheus margaritatus ammonite Biozone at Brenha and Peniche (Figs. 4; 5). This range base is consistent with records from northwest Europe (Morgenroth, 1970; Woollam and Riding, 1983; Bucefalo Palliani and Riding, 2003; Poulsen and Riding, 2003). The range tops of consistent occurrences of Nannoceratopsis gracilis and Nannoceratopsis senex are in the lower Bajocian Stephanoceras humphriesianum ammonite Biozone (Poulsen and Riding, 2003, p. 124; Wiggan et al., 2017, table 2a). Nannoceratopsis ambonis is present in the Dactylioceras polymorphum ammonite Biozone at Maria Pares, Peniche and Vale das Fontes, and an isolated occurrence in the upper Toarcian (Hammatoceras speciosum ammonite Biozone) at Maria Pares (supplementary Tables 3, 5; Correia et al., 2017a). Nannoceratopsis gracilis and Nannoceratopsis senex occur consistently, and in relatively high proportions, throughout the Dactylioceras polymorphum ammonite Biozone at Maria Pares, Peniche and Vale das Fontes. The genus disappeared at the base of Hildaites levisoni ammonite Biozone in these three lower Toarcian successions (supplementary Tables 3, 5; Correia et al., 2017a). This event is interpreted to be a result of the palaeoenvironmental perturbations associated with the T-OAE in the Lusitanian Basin (e.g., Duarte et al., 2004; Hesselbo et al., 2007; Suan et al., 2008, 2010; Pittet et al., 2014; Correia et al., 
572 Toarcian (Hammatoceras speciosum to Pleydellia aalensis ammonite biozones) at

573 Maria Pares (supplementary Table 5).

574 The distinctive gonyaulacacean species Scriniocassis weberi and Scriniocassis

575 priscus were encountered, normally in low proportions, in the Toarcian of the

576 Lusitanian Basin (Fig. 13; supplementary Tables 3, 5). Scriniocassis weberi ranges

577 throughout the late Pliensbachian to early Aalenian, and Scriniocassis priscus is

578 confined to the middle Toarcian to Aalenian, in northwest Europe (Riding, 1984a,b;

579 Prauss, 1989; Feist-Burkhardt, 1990; Feist-Burkhardt and Wille, 1992; Feist-Burkhardt

580 and Pross, 2010). At Peniche, Scriniocassis weberi was found in small numbers in the

581 middle part of the Dactylioceras polymorphum ammonite Biozone (supplementary

582 Table 3; Correia et al., 2017b). By contrast, Scriniocassis priscus was sporadic, yet

583 relatively common where present, between the Toarcian Hildoceras bifrons and

584 Hammatoceras speciosum ammonite biozones at Maria Pares, and apparently can be

585 used as a marker for this interval in the Lusitanian Basin (Fig. 13).

The pollen-spore floras are generally not as biostratigraphically important as the

587 dinoflagellate cysts. However, there are several miospore datums in the Maria Pares section which are noteworthy. The range base of Callialasporites spp. is in the Brodieia gradata ammonite Biozone of the middle Toarcian (supplementary Table 5). This biovent is consistent with other reports that the inception of this distinctive pollen genus is in the latest early Toarcian (Riding et al., 1991). Apparently, the range top of the

592 spore Kraeuselisporites reissingeri is in sample P33, within the Hildaites levisoni

593 ammonite Biozone. This bioevent is broadly consistent with the findings of Morbey

594 (1978, fig. 1). The distinctive spore Kekryphalospora distincta was encountered in sample PZ82 (Dumortieria meneghinii ammonite Biozone) at Maria Pares 
596 (supplementary Table 5). This occurrence is well within the known range of late

597 Pliensbachian to early Bajocian (Fenton and Riding, 1987).

598

599

6. The Pliensbachian-Toarcian dinoflagellate cyst biozonation of the

600

Lusitanian Basin

601

\subsection{Introduction}

602

Due their relatively short ranges, many Jurassic dinoflagellate cysts are reliable

603

stratigraphical markers, and several biozonation schemes have been defined based on

604

them (Woollam and Riding, 1983; Helby et al., 1987; Riding and Thomas, 1992;

605

Poulsen and Riding, 2003; Riding et al., 2010). A new dinoflagellate cyst biozonation

606

for the upper Pliensbachian to upper Toarcian of the Lusitanian Basin is summarised in

607

Fig. 13, and compared with the schemes of Riding and Thomas (1992) and Poulsen and

608

Riding (2003).

609

610 6.2. The Luehndea spinosa dinoflagellate cyst Biozone

611 Definition: The interval from the range bases of Luehndea spinosa, Nannoceratopsis

612 gracilis and Nannoceratopsis senex, to the range top of Luehndea spinosa.

613 Age: Late Pliensbachian (base of Amaltheus margaritatus ammonite Biozone) to

614 earliest Toarcian (top of the Dactylioceras polymorphum ammonite Biozone).

615 Characteristics: The dominance of Luehndea spinosa and the relatively consistent and

616 frequent presence of Mancodinium semitabulatum, Nannoceratopsis gracilis and

617 Nannoceratopsis senex. The inception of abundant Luehndea spinosa allows the

618 consistent subdivision of this biozone.

619 Comments: The Luehndea spinosa dinoflagellate cyst Biozone of the Lusitanian Basin

620 is coeval with the Luehndea spinosa Total Range Biozone of Riding and Thomas (1992, 
621 p. 20-21) and the Luehndea spinosa Biozone of Poulsen and Riding (2003), both of

622 northwest Europe (Fig. 13). All these three biozones are defined by the range base of

623 Luehndea spinosa and other taxa, such as Nannoceratopsis senex or Nannoceratopsis

624 gracilis at the base, to the range top of Luehndea spinosa at the top. The

625 Nannoceratopsis senex and Luehndea spinosa subbiozones are broadly equivalent to

626 subbiozones a and b of Riding and Thomas (1992), respectively (Fig. 13).

627

628

6.2.1. The Nannoceratopsis senex dinoflagellate cyst Subbiozone

629

Definition: The interval from the range base of Luehndea spinosa, to the range base of

630 the abundant presence of this species.

631 Age: Late Pliensbachian (base of Amaltheus margaritatus ammonite Biozone) to latest

632 Pliensbachian (close to the top of the Emaciaticeras emaciatum ammonite Biozone.

633 Characteristics: Luehndea spinosa is typically present in relatively low abundances in

634 this Subbiozone.

635

636 6.2.2. The Luehndea spinosa dinoflagellate cyst Subbiozone

637 Definition: The interval from the range base of the abundant presence of Luehndea

638 spinosa, to the range top of this species.

639 Age: Latest Pliensbachian (close to the top of the Emaciaticeras emaciatum ammonite

640 Biozone) to earliest Toarcian (top of the Dactylioceras polymorphum ammonite

641 Biozone).

642 Characteristics: Luehndea spinosa is consistently present, and largely in high

643 abundances.

644

645 6.3. The Mendicodinium microscabratum dinoflagellate cyst Biozone 
646 Definition: The interval from the range top of Luehndea spinosa, to the apparent range 647 top of Mendicodinium microscabratum.

648 Age: Early Toarcian (base of the Hildaites levisoni ammonite Biozone) to late Toarcian 649 (top of the Hammoteceras speciosum ammonite Biozone).

650 Characteristics: This biozone typically exhibits low abundances and diversities of 651 dinoflagellate cysts. Mancodinium semitabulatum, Mendicodinium microscabratum and 652 Scriniocassis priscus may be present (Fig. 13).

653 Comments: This biozone is partially equivalent to the Nannoceratopsis gracilis Interval 654 Biozone of Riding and Thomas (1992, p. 21-25), but the latter extends into the early 655 Bajocian in northwest Europe. In the Lusitanian Basin, the top of this biozone is 656 presently not well defined. Nannoceratopsis gracilis subbiozones a and b of Riding and 657 Thomas (1992) are correlated with the Mancodinium semitabulatum and 658 Mendicodinium microscabratum subbiozones herein respectively. Furthermore, the 659 Mancodinium semitabulatum and Mendicodinium microscabratum subbiozones herein, 660 correspond to the Mancodinium semitabulatum and Parvocysta nasuta biozones of 661 Poulsen and Riding (2003). This study represents the youngest record of Mendicodinium microscabratum in the the middle and upper Toarcian (Fig. 13). Bucefalo Palliani et al. (1997a) reported this species from the lower Toarcian of Italy. Other coeval sections, and younger strata, should be studied in the Lusitanian Basin and adjacent regions in order to confirm if the range top of this species is at the top of Hammoteceras speciosum ammonite Biozone. Using the apparent range top of Mendicodinium microscabratum, and the reappearance of Nannoceratopsis senex, the base of another dinoflagellate cyst biozone could possibly be defined at, or close to, the base of the Dumortieria meneghinnii 
671 Basin, we opted not to erect another dinoflagellate cyst biozone until more information

672 becomes available.

673

674 6.3.1. The Mancodinium semitabulatum dinoflagellate cyst Subbiozone

675 Definition: The interval from the range top of Luehndea spinosa, to the range base of

676 Scriniocassis priscus.

677 Age: Early Toarcian (base of the Hildaites levisoni ammonite Biozone) to middle

678 Toarcian (close to the top of the Hildoceras bifrons ammonite Biozone).

679 Characteristics: The only dinoflagellate cysts present are rare Mancodinium

680 semitabulatum and Mendicodinium microscabratum.

681

682

6.3.2. The Mendicodinium microscabratum dinoflagellate cyst Subbiozone

683

Definition: The interval from the range base of Scriniocassis priscus, to the apparent

684

range top of Mendicodinium microscabratum.

685

Age: Middle Toarcian (close to the top of the Hildoceras bifrons ammonite Biozone) to late Toarcian (top of the Hammoteceras speciosum ammonite Biozone).

687

Characteristics: Mendicodinium microscabratum is the dominant dinoflagellate cyst

688 species in a very low diversity flora.

689

690

\section{Conclusions}

691

The Lower Jurassic palynology of the Lusitanian Basin of western Portugal was comprehensively investigated, with the principal emphasis on dinoflagellate cysts. A

693

Sinemurian to Toarcian composite succession from six sections throughout this

694 important depocentre was constructed. The Sinemurian proved entirely devoid of

695 dinoflagellate cysts, but the overlying Pliensbachian and Toarcian succession is 
characterised by relatively low dinoflagellate cyst diversity; fifteen taxa were encountered. Only seven genera were recorded with certainty, these are Luehndea, Mancodinium, Mendicodinium, Nannoceratopsis, Scriniocassis, Sentusidinium and Valvaeodinium.

The dinoflagellate cyst succession in the Lusitanian Basin is broadly consistent with other Lower Jurassic sedimentary basins in Europe. However, the reliable Upper Sinemurian dinoflagellate cyst Liasidium variabile appears not to have migrated south into the Lusitanian Basin from northwest Europe. Luehndea spinosa is the dominant palynomorph in the lowermost Toarcian (Dactylioceras polymorphum ammonite Biozone), and is the most age-diagnostic species. At the base of Hildaites levisoni ammonite Biozone, Luehndea spinosa became extinct, probably due to the effects of the T-OAE. Also at this time, dinoflagellate cyst abundance and diversity sharply decreased. The recovery of phytoplankton during the middle and late Toarcian was relatively slow, following the T-OAE.

Other palynomorph groups such as acanthomorph acritarchs, foraminiferal test linings, pollen and spores, and prasinophytes were also documented. The pollen species Classopollis classoides is the most common and abundant palynomorph throughout the Lower Jurassic strata of the Lusitanian Basin. The non-dinoflagellate cyst taxa encountered exhibit no discernible trend, or stratigraphical succession.

By contrast, the dinoflagellate cysts Luehndea spinosa, Mancodinium semitabulatum, Mendicodinium microscabratum, Nannoceratopsis gracilis, Nannoceratopsis senex and Scriniocassis priscus were relatively frequent and proved to have biostratigraphical significance. Two dinoflagellate cyst biozones were defined for the succession studied. These are the Luehndea spinosa and the Mendicodinium microscabratum biozones which are of late Pliensbachian-earliest Toarcian, and 
earliest-late Toarcian age respectively. These two dinoflagellate cyst biozones are each subdivided into two subbiozones.

\section{Acknowlegements}

The contribution of Vânia F. Correia is part of her PhD scholarship

SFRH/BD/93950/2013, awarded by the Portuguese Foundation for Science and Technology (FCT). James B. Riding publishes with the approval of the Executive Director, British Geological Survey (NERC). Luís V. Duarte was supported by FCT, through the strategic project UID/MAR/04292/2013 granted to the Marine and Environmental Sciences Centre (MARE).

\section{Appendix}

This is a list of all the palynomorphs which were recovered from the material studied herein, or mentioned in the text, with full author citations. The seven species listed which were not found in the material from the Lusitanian Basin are asterisked. The taxa are listed alphabetically in four groups. References to the dinoflagellate cyst author citations can be found in Williams et al. (2017). The recommendations of Correia et al. (2017a, appendix 2) regarding the taxonomy of Nannoceratopsis senex are followed herein.

\section{Dinoflagellate cysts:}

Dapsilidinium? deflandrei (Valensi, 1947) Lentin \& Williams 1981

*Liasidium variabile Drugg 1978

*Luehndea cirilliae Bucefalo Palliani et al., 1997

Luehndea spinosa Morgenroth 1970

Mancodinium semitabulatum Morgenroth 1970 
746 *Mendicodinium brunneum Bucefalo Palliani et al. 1997

747 Maturodinium inornatum Morgenroth 1970

748 Mendicodinium microscabratum Bucefalo Palliani et al. 1997

749 Mendicodinium spinosum Bucefalo Palliani et al. 1997 subsp. spinosum (autonym)

750 *Mendicodinium umbriense Bucefalo Palliani et al. 1997

$751 \quad$ Nannoceratopsis ambonis Drugg 1978

752 Nannoceratopsis gracilis Alberti 1961

$753 \quad$ Nannoceratopsis senex van Helden 1977

754 Scriniocassis priscus (Gocht 1979) Below 1990

755 Scriniocassis weberi Gocht 1964

756 *Susadinium scrofoides Dörhöfer \& Davies 1980

757 *Umbriadinium mediterraneense Bucefalo Palliani \& Riding 1997

758 *Valvaeodinium hirsutum Bucefalo Palliani \& Riding 1997

759 Miscellaneous microplankton:

760 Halosphaeropsis liassica Mädler 1968

761 Polygonium jurassicum Bucefalo Palliani et al. 1996

762 Pollen:

763 Araucariacites australis Cookson 1947 ex Couper 1958

764 Callialasporites dampieri (Balme 1957) Dev 1961

765 Callialasporites turbatus (Balme 1957) Schulz 1967

766 Cerebropollenites macroverrucosus (Thiergart 1949) Schulz 1967

767 Classopollis classoides (Pflug 1953) Pocock \& Jansonius 1961

768 Spores:

769 Ischyosporites variegatus (Couper 1958) Schulz 1967

$770 \quad$ Kekryphalospora distincta Fenton \& Riding 1987 
Kraeuselisporites reissingeri (Harris 1957) Morbey 1975

Lycopodiacidites rugulatus (Couper 1958) Schulz 1967

773

Plicifera delicata (Bolchovitina 1953) Bolchovitina 1966

774

775

\section{References}

776

777 Azerêdo, A.C., Duarte, L.V., Henriques, M.H., Manuppella, G., 2003. Da dinâmica continental no Triássico aos mares do Jurássico Inferior e Médio. Cadernos de Geologia de Portugal, Instituto Geológico e Mineiro, Lisboa, 43 pp.

780

Azerêdo, A.C., Duarte, L.V., Silva, R.L., 2014. Configuração sequencial em ciclos (2a ordem) de fácies transgressivas-regressivas do Jurássico Inferior e Médio da Bacia Lusitânica (Portugal). Comunicações Geológicas 101 (Especial I), 383-386.

784

Baldanza, A., Bucefalo Palliani, R., Mattioli, E., 1995. Calcareous nannofossils and dinoflagellate cysts from Late Liassic of Hungary and comparison with central Italy assemblages. Paleopelagos 5, 161-174.

788

789

Baranyi, V., Pálfy, J., Görög, A., Riding, J.B., Raucsik, B., 2016. Multiphase response 790 of palynomorphs to the Toarcian Oceanic Anoxic Event (Early Jurassic) in the Réka Valley section, Hungary. Review of Palaeobotany and Palynology 235, 51-70.

Barrón, E., Azerêdo, A.C., 2003. Palynology of the Jurassic (Callovian-Oxfordian) succession from Pedrógão (Lusitanian Basin, Portugal). Palaeoecological and 
palaeobiogeographical aspects. Neues Jahrbuch für Geologie und Paläontologie

Abhandlungen 227, 259-286.

797

798

Barrón, E., Comas-Rengifo, M.J., Duarte, L.V., 2013. Palynomorph succession of the

Upper Pliensbachian-Lower Toarcian of the Peniche section (Portugal). Comunicações

800 Geológicas 100 (Especial I), 55-61.

801

802 Bomfleur, B., Schöner, R., Schneider, J.W., Viereck, L., Kerp, H., McKellar, J.L., 2014.

803 From the Transantarctic Basin to the Ferrar Large Igneous Province: New

804 palynostratigraphic age constraints for Triassic-Jurassic sedimentation

805 and magmatism in East Antarctica. Review of Palaeobotany and Palynology 207, 18

80637.

807

808

Boussaha, M., Pittet, B., Mattioli, E., Duarte, L.V., 2014. Spatial characterization of the

809

late Sinemurian (Early Jurassic) palaeoenvironments in the Lusitanian Basin.

810 Palaeogeography, Palaeoclimatology, Palaeoecology 409, 320-339.

811

812 Brittain, J.M., Higgs, K.T., Riding, J.B., 2010. The palynology of the Pabay Shale

813 Formation (Lower Jurassic) of SW Raasay, northern Scotland. Scottish Journal of

814 Geology 46, 67-75.

815

816 Bucefalo Palliani, R., Riding, J.B., 1997a. Lower Toarcian palynostratigraphy of

817 Pozzale, central Italy. Palynology 21, 91-103.

818 
Bucefalo Palliani, R., Riding, J.B., 1997b. The influence of palaeoenvironmental change on dinoflagellate cyst distribution. An example from the Lower and Middle Jurassic of Quercy, southwest France. Bulletin des Centres de Recherches Exploration Production Elf-Aquitaine 21, 107-123.

Bucefalo Palliani, R., Riding, J.B., 1997c. Umbriadinium mediterraneense gen. et sp. nov. and Valvaeodinium hirsutum sp. nov.: two dinoflagellate cysts from the Lower Jurassic of the Tethyan Realm. Palynology 21, 197-206.

Bucefalo Palliani, R., Riding, J.B., Torricelli, S., 1997a. The dinoflagellate cyst Mendicodinium Morgenroth, 1970, emend. from the lower Toarcian (Jurassic) of central Italy. Review of Palaeobotany and Palynology 96, 99-111.

Bucefalo Palliani, R., Riding, J.B., Torricelli, S., 1997b. The dinoflagellate cyst Luehndea Morgenroth, 1970, emend. from the upper Pliensbachian (Lower Jurassic) of Hungary. Review of Palaeobotany and Palynology 96, 113-120.

Bucefalo Palliani, R., Riding, J.B., 1999a. Early Jurassic (Pliensbachian-Toarcian) dinoflagellate migrations and cyst paleoecology in the Boreal and Tethyan realms. Micropaleontology 45, 201-214.

Bucefalo Palliani, R., Riding, J.B., 1999b. Relationships between the early Toarcian anoxic event and organic-walled phytoplankton in central Italy. Marine Micropaleontology 37, 101-116. 
844 Bucefalo Palliani, R., Riding, J.B., 2000. A palynological investigation of the Lower and lowermost Middle Jurassic strata (Sinemurian to Aalenian) from North Yorkshire,

Bucefalo Palliani, R., Mattioli, E., Riding, J.B., 2002. The response of marine phytoplankton and sedimentary organic matter to the early Toarcian (Lower Jurassic) oceanic anoxic event in northern England. Marine Micropaleontology 46, 223-245.

851

Bucefalo Palliani, R., Riding, J.B., 2003. Biostratigraphy, provincialism and evolution of European Early Jurassic (Pliensbachian to early Toarcian) dinoflagellate cysts. Palynology 27, 179-214.

855

Butler, N., Charnock, M.A., Hager, K.O., Watkins, C.A., 2005. The Ravenscar Group: a coeval analogue for the Middle Jurassic reservoirs of the North Sea and offshore MidNorway, in: Powell, A.J., Riding, J.B. (Eds.), Recent Developments in Applied Biostratigraphy. The Micropalaeontological Society, Special Publications. The Geological Society, London, U.K., pp. 43-53.

861

Cabral, M.C., Colin, J.P., Azerêdo, A.C., Silva, R.L., Duarte, L.V., 2015. Brackish and marine ostracode assemblages from the Sinemurian of western Portugal, with descriptions of new species. Micropaleontology 61 (1-2), 3-24.

865

866 Cabral, M.C., Lord, A., Boomer, I., Loureiro, I., Malz, H., 2014. Tanycithere new genus 867 and its significance for Jurassic ostracoda diversity. Journal of Palaeontology 88 (3), $868519-530$. 
870 Comas-Rengifo, M.J., Duarte, L.V., Felix, F.F., Goy, A., Paredes, R., Silva, R. L.

871 (2016). Amaltheidae e Hildoceratidae (ammonitina) del Pliensbachiense Superior

872 (Cronozona Spinatum) en las cuencas septentrionales de la Península Ibérica, in:

873 Meléndez, G., Núñez, A., Tomás, M. (Eds.), Actas de las XXXII Jornadas de la

874 Sociedad Española de Paleontología. Cuadernos del Museo Geominero no 20. Instituto

875 Geológico y Minero de España, Madrid, pp. 47-52.

876

877 Correia, V.F., Riding, J.B., Fernandes, P., Duarte, L.V., Pereira, Z. 2017a. The

878 palynology of the lower and middle Toarcian (Lower Jurassic) in the northern

879 Lusitanian Basin, western Portugal. Review of Palaeobotany and Palynology 237, 75-

88095.

881

882 Correia, V.F., Riding, J.B., Fernandes, P., Duarte, L.V., Pereira, Z. 2017b. The

883 palynological response to the Toarcian Oceanic Anoxic Event (Early Jurassic) at

884 Peniche, Lusitanian Basin, western Portugal. Marine Micropaleontology, in review.

885

886 Davey, R.J., Riley, L.A. 1978. Late and Middle Jurassic dinoflagellate cysts, in: Thusu,

887 B. (Ed.), Distribution of biostratigraphically dfiagnostic dinoflagellate cysts and

888 miospores from the northwest European continental shelf and adjacent areas.

889 Continental Shelf Institute Publication 100, pp. 51-45.

890

891 Davies, E.H., 1985. The miospore and dinoflagellate cyst Oppel-Zonation of the Lias of

892 Portugal. Palynology 9, 105-132.

893 
894

895

896

897

898

899

900

901

902

903

904

905

906

907

908

909

910

911

912

913

914

915

916

917

Duarte, L.V., 1995. O Toarciano da Bacia Lusitaniana. Estratigrafia e evolução sedimentogénica. Ph.D. thesis, Universidade de Coimbra, Portugal (unpublished), 349 pp.

Duarte, L.V., 1997. Facies analysis and sequential evolution of the Toarcian-Lower Aalenian series in the Lusitanian Basin (Portugal). Comunicações do Instituto Geológico e Mineiro 83, 65-94.

Duarte, L.V., 2007. Lithostratigraphy, sequence stratigraphy and depositional setting of the Pliensbachian and Toarcian series in the Lusitanian Basin, Portugal, in: Rocha, R.B. (Ed.), The Peniche section (Portugal). Contributions to the definition of the Toarcian GSSP. International Subcommission on Jurassic Stratigraphy, ISBN 978-972-8893-149, pp. 17-23.

Duarte, L.V., Krautter, M., Soares, A.F., 2001. Bioconstructions à spongiaires siliceux dans le Lias terminal du Bassin Lusitanien (Portugal): stratigraphie, sédimentologie et signification paléogéographique. Bulletin Société Géologique de France 172, 637-646.

Duarte, L.V., Soares, A.F., 2002. Litostratigrafia das séries margo-calcárias do Jurássico inferior da Bacia Lusitânica (Portugal). Comunicações do Instituto Geológico e Mineiro $89,135-154$.

Duarte, L.V., Perilli, N., Dino, R., Rodrigues, R., Paredes, R., 2004. Lower to Middle Toarcian from the Coimbra region (Lusitanian Basin, Portugal): sequence stratigraphy, 
920

921

922

923

924

925

926

927

928

929

930

931

932

933

934

935

936

937

938

939

940

941

942

calcareous nannofossils and stable-isotope evolution. Rivista Italiana di Paleontologia e Stratigrafia 100, 115-127.

Duarte, L.V., Oliveira, L.C., Rodrigues, R., 2007. Carbon isotopes as a sequence stratigraphic tool: examples from the Lower and Middle Toarcian marly limestones of Portugal. Boletín Geológico y Minero 118, 3-17.

Duarte, L.V., Silva, R.L., Oliveira, L.C.V., Comas-Rengifo, M.J., Silva, F., 2010.

Organic-rich facies in the Sinemurian and Pliensbachian of the Lusitanian Basin, Portugal: total organic carbon distribution and relation to transgressive-regressive facies cycles. Geologica Acta 8, 325-340.

Duarte, L.V., Silva, R.L., Mendonça Filho, J.G., Poças Ribeiro, N., Chagas, R.B.A., 2012. High resolution stratigraphy, palynofacies and source rock potential of the Água de Madeiros Formation (Lower Jurassic), Lusitanian Basin, Portugal. Journal of Petroleum Geology 35 (2), 105-126.

Duarte, L.V., Comas-Rengifo, M.J., Silva, R.L., Paredes, R., Goy, A., 2014a. Carbon isotope stratigraphy and ammonite biochronostratigraphy across the SinemurianPliensbachian boundary in the western Iberian margin. Bulletin of Geosciences 89, 719738.

Duarte, L. V., Silva, R. L., Mendonça Filho, J. G., Azerêdo, A. C., Cabral, M. C., Comas-Rengifo, M. J., Correia, G., Ferreira, R., Loureiro, I. M., Paredes, R., Pereira, A., Ribeiro, N. P., 2014b. Advances in the Stratigraphy and Geochemistry of the 
Organic-Rich Lower Jurassic Series of the Lusitanian Basin (Portugal), in: Rocha, R.B., Pais, J., Kullberg, J.C., Finney, S. (Eds.), STRATI 2013. Springer International Publishing, pp. 841 - 846., doi: 10.1007/978-3-319-04364-7_158.

Duarte, L.V, Silva, R.L., Félix, F., Comas-Rengifo. M.J., Rocha, R.B., Mattioli, E., Paredes, R., Mendonça Filho, J. G., Cabral, M.C., 2017. The Jurassic of the Peniche Peninsula (Portugal): scientific, educational and science popularization relevance. Revista de la Sociedad Geológica de España 30(1), in press.

Elmi, S., 2006. Pliensbachian/Toarcian boundary: the proposed GSSP of Peniche (Portugal). Volumina Jurassica 4, 5-16.

Elmi, S., Rocha, R.B., Mouterde, R., 1988. Sediméntation pelagique et encroûtements crytalgaires: les calcaires grumeleux du Carixien portugais. Ciências da Terra 9, 69-90.

Elmi, S., Goy, A., Mouterde, R., Rivas, P., Rocha, R., 1989. Correlaciones bioestratigráficas en el Toarciense de la Peninsula Iberica. Cuadernos de Geologia Iberica 13, 265-277.

Feist-Burkhardt, S., 1990. Dinoflagellate cyst assemblages from the Hausen coreholes (Aalenian to early Bajocian), southwest Germany. Bulletin des Centres de Recherches Exploration-Production Elf-Aquitaine 14, 611-633.

Feist-Burkhardt, S., Wille, W., 1992. Jurassic palynology in southwest Germany - state of the art. Cahiers de Micropaléontologie N.S. 7, 141-156. 
969 Feist-Burkhardt, S., Pross, J., 2010. Dinoflagellate cyst biostratigraphy of the

970 Opalinuston Formation (Middle Jurassic) in the Aalenian type area in southwest

971 Germany and north Switzerland. Lethaia 43, 10-31.

972

973 Fenton, J.P.G., Riding, J.B., 1987. Kekryphalospora distincta gen. et sp. nov., a trilete

spore from the Lower and Middle Jurassic of north-west Europe. Pollen et Spores 29,

975 $427-434$.

976

977 Ferreira, J., Mattioli, E., Pittet, B., Cachão, M., Spangenberg, J.E., 2015. Palaeoecological 978 insights on Toarcian and lower Aalenian calcareous nannofossils from the Lusitanian 979 Basin (Portugal). Palaeogeography, Palaeoclimatology, Palaeoecology, 436, 245-262.

980

981 Helby, R., Morgan, R., Partridge, A.D., 1987. A palynological zonation of the 982 Australian Mesozoic. Memoir of the Association of Australasian Palaeontologists 4, 198394.

984

985

Henriques, M.H., 1992. Biostratigrafia e paleontologia (Ammonoidea) do Aaleniano em

986

Portugal (Sector Setentrional da Bacia Lusitaniana). Ph.D. thesis, Universidade de

987 Coimbra, Portugal (unpublished), $301 \mathrm{pp}$.

988

989 Henriques, M.H., 1995. Les faunes d'ammonites de l'Aalénien Portugais: composition 990 et implications paléobiogéographiques, in: Gayet, M., Courtinat, B. (Eds.), First

991 European Palaeontological Congress, Lyon, 1993. Geobios, Mémoire Spécial 18, 229992235. 
994 Henriques, M.H., Canales, M.L., 2013. Ammonite-benthic foraminifera turnovers

995

across the Lower-Middle Jurassic transition in the Lusitanian Basin (Portugal). Geobios

996

$46,395-408$.

997

998

Henriques, M.H., Canales, M.L., Figueiredo, V., García-Frank, A., Hernández, L.,

999

Silva, S., Ureta, S., 2014. Biostratigrafia integrada (ammonoidea, foraminiferida) da

1000

passagem Jurássico Inferior-Médio na Península Ibérica: resultados preliminares.

1001

Comunicações Geológicas 101 (Especial I), 443-446.

1002

1003

Hesselbo, S.P., Jenkyns, H.C., Duarte, L.V., Oliveira, L.C.V., 2007. Carbon-isotope

1004

record of the Early Jurassic (Toarcian) Oceanic Anoxic Event from fossil wood and

1005

marine carbonate (Lusitanian Basin, Portugal). Earth and Planetary Science Letters 253,

1006 $455-470$.

1007

1008

Jenkyns, H.C., 2010. Geochemistry of oceanic anoxic events, Geochemistry Geophysics

1009 Geosystems 11, Q03004, doi:10.1029/2009GC002788.

1010

1011 Koppelhus, E.B., Nielsen, L.H., 1994. Palynostratigraphy and palaeoenvironments of

1012 the Lower to Middle Jurassic Bagå Formation of Bornholm, Denmark. Palynology 18, 1013 139-194.

1014

1015 Kullberg, J.C., Rocha, R.B., Soares, A.F., Rey, J., Terrinha, P., Azerêdo, A.C.,

1016 Callapez, P., Duarte, L.V., Kullberg, M.C., Martins, L., Miranda, J.R., Alves, C., Mata, 
1017

1018

1019

1020

1021

1022

1023

1024

1025

1026

1027

1028

1029

1030

1031

1032

1033

1034

1035

1036

1037

1038

1039

1040

J., Madeira, J., Mateus, O., Moreira, M., Nogueira, C.R., 2013. A Bacia Lusitaniana: estratigrafia, paleogeografia e tectónica. Geologia de Portugal 2, 195-347.

Mattioli, E., Plancq, J., Boussaha, M., Duarte, L.V., Pittet, B., 2013. Calcareous

nannofossil biostratigraphy: new data from the Lower Jurassic of the Lusitanian Basin.

Comunicações Geológicas 100 (Especial I), 69-76.

Mohr, B.A.R., Schmidt, D., 1988. The Oxfordian/Kimmeridgian boundary in the region of Porto de Mós (central Portugal): stratigraphy, facies and palynology. Neues Jahrbuch für Geologie und Paläontologie Abhandlungen 176, 245-267.

Morbey, S.J., 1978. Late Triassic and Early Jurassic subsurface palynostratigraphy in northwestern Europe. Palinologia número extraordinario 1, 355-365.

Morgenroth, P., 1970. Dinoflagellate cysts from the Lias Delta of Lühnde/Germany.

Neues Jahrbuch für Geologie und Paläontologie Abhandlungen 136, 345-359.

Mouterde, R., Ruget, C., Moitinho de Almeida, F., 1964-1965. Coupe du Lias au Sud de Condeixa. Comunicações dos Serviços Geológicas de Portugal 48, 61-91.

Mouterde, R., Rocha, R.B., Ruget, C., 1978. Stratigraphie et faune du Lias et de la base du Dogger au Nord du Mondego (Quaios et Brenha). Comunicações dos Serviços Geológicas de Portugal 63, 83-103. 
1041

1042

1043

1044

1045 Oliveira, L.C.V., Duarte, L.V., Lemos, V.B., Comas-Rengifo, M.J., Perilli, N., 2007a.

1046 Bioestratigrafia de nanofósseis calcários e correlação com as zonas de amonites do

1047 Pliensbaquiano-Toarciano basal (Jurássico inferior) de Peniche (Bacia Lusitânica,

1048

1049

1050

1051

1052

1053

1054

1055

1056

1057

1058

1059

1060

1061

1062

1063

1064

1065

Mouterde, R., Rocha, R.B., Ruget, C., Tintan, H., 1979. Faciès, biostratigraphie et paléogéographie du Jurassique portugais. Ciências da Terra, Universidade Nova de Lisboa 5, 29-52.

\section{Pliensbaquiano-Toarciano basal (Jurássico inferior) de Peniche (Bacia Lusitannica,}

Portugal), in: Carvalho, I.S., Cassab, R.C.T., Schwanke, C., Carvalho, M.A., Fernandes,

A.C.S., Rodrigues, M.A.C., Carvalho, M.S.S., Arai, M., Oliveira, M.E.Q. (Eds.),

Paleontologia: Cenários de Vida. Proceedings of XIX Congresso Brasileiro de

Paleontologia, Búzios (Brazil), Editora Interciência, pp. 411-420.

Oliveira, L.C.V., Dino, R., Duarte, L.V., Perilli, N., 2007b. Calcareous nannofossils and palynomorphs from Pliensbachian-Toarcian boundary in Lusitanian Basin, Portugal.

Revista Brasileira de Paleontologia 10, 5-16.

Paredes, R., Comas-Rengifo, M.J., Duarte, L.V., 2016. Passagem Pliensbaquiano-

Toarciano: a diversidade de macroinvertebrados antes da extinção, in: Duarte, L.V.,

Sêco, S. (Eds.), “O Jurássico da região de Penela: novos avanços no conhecimento

estratigráfico”, pp. 30-34. ISBN (digital): 978-989-97997-3-8.

Perilli, N., Duarte, L.V., 2006. Toarcian nannobiohorizons from Lusitanian Basin

(Portugal) and their calibration against ammonite zones. Revista Italiana di

Paleontologia e Stratigrafia 112, 417-434. 
1066

1067

1068

1069

1070

1071

1072

1073

1074

1075

1076

1077

1078

1079

1080

1081

1082

1083

1084

1085

1086

1087

1088

1089

Phelps, M., 1985. A refined ammonite biostratigraphy for the Middle and Upper

Carixian (Ibex and Davoei zones, Lower Jurassic) in North-West Europe and

stratigraphical details of the Carixian-Domerian boundary. Geobios 18, 321-362.

Pinto, S., 2008. Ostracodos do Toarciano da Bacia Lusitânica (Peniche e Alvaiázare) sistemática, aspectos biosestratigráficos, paleoecológicos e palaebiogeográficos. M.Sc. thesis, Universidade de Lisboa, Portugal (unpublished), $174 \mathrm{p}$.

Pittet, B., Suan, G., Lenoir, F., Duarte, L.V., Mattioli, E., 2014. Carbon isotope evidence for sedimentary discontinuities in the Lower Toarcian of the Lusitanian Basin (Portugal): Sea level change at the onset of the Oceanic Anoxic Event. Sedimentary Geology 303, 1-14.

Plancq, J., Mattioli, E., Pittet, B., Baudin, F., Duarte, L.V., Boussaha, M., Grossi, V., 2016. A calcareous nannofossil and organic geochemical study of marine palaeoenvironmental changes across the Sinemurian/Pliensbachian (early Jurassic, 191 Ma) in Portugal. Palaeogeography, Palaeoclimatology, Palaeoecology 449, 1-12.

Poulsen, N.E., Riding, J.B., 2003. The Jurassic dinoflagellate cyst zonation of Subboreal Northwest Europe. Geological Survey of Denmark and Greenland Bulletin 1, $115-144$.

Poças Ribeiro, N., Mendonça Filho, J.G., Duarte, L.V., Silva, R.L., Mendonça, J.O., Silva, T.F., 2013. Palynofacies and organic geochemistry of the Sinemurian carbonate 
1090 deposits in the western Lusitanian Basin (Portugal): Coimbra and Água de Madeiros

formations. International Journal of Coal Geology 111, 37-52.

1092

1093

Prauss, M., 1989. Dinozysten-stratigraphie und Palynofazies im Oberen Lias und

Dogger von NW-Deutschland. Palaeontographica Abteilung B 214, 1-124.

1095

1096

Quattrocchio, M.E., Volkheimer, W., Borromei, A.M., Martínez, M.A., 2011. Changes

1097

of the palynobiotas in the Mesozoic and Cenozoic of Patagonia: a review. Biological

1098

Journal of the Linnean Society 103, 380-396.

1099

1100 Reggiani, L., Mattioli, E., Pittet, B., Duarte, L.V., Veiga de Oliveira, L.C., Comas-

1101

Rengifo, M.J., 2010. Pliensbachian (Early Jurassic) calcareous nannofossils from the

Peniche section (Lusitanian Basin, Portugal): a clue for palaeoenvironmental

1103

reconstructions. Marine Micropaleontology 75 (1-4), 1-16.

1104

1105

Riding, J.B., 1984a. A palynological investigation of Toarcian to early Aalenian strata 1106

from the Blea Wyke area, Ravenscar, North Yorkshire. Proceedings of the Yorkshire 1107 Geological Society 46, 109-122.

1108

Riding, J.B., 1984b. Dinoflagellate cyst range-top biostratigraphy of the uppermost

Triassic to lowermost Cretaceous of northwest Europe. Palynology 8, 195-210.

1112 Riding, J.B., 1987. Dinoflagellate cyst stratigraphy of the Nettleton Bottom Borehole

1113 (Jurassic: Hettangian to Kimmeridgian), Lincolnshire, England. Proceedings of the

1114 Yorkshire Geological Society 46, 231-266. 
1116 Riding, J.B., Walton, W., Shaw, D., 1991. Toarcian to Bathonian (Jurassic) palynology

1117 of the Inner Hebrides, northwest Scotland. Palynology 15, 115-179.

1119 Riding, J.B., Thomas, J.E., 1992. Dinoflagellate cysts of the Jurassic System, in:

1120 Powell, A.J. (Ed.), A stratigraphic index of dinoflagellate cysts. British

1121 Micropalaeontological Society Publications Series. Chapman and Hall, London, pp. 7112297

1123 Riding, J.B., Hubbard, R.N.L.B., 1999. Jurassic (Toarcian to Kimmeridgian)

1124 dinoflagellate cysts and paleoclimates. Palynology 23, 15-30.

Riding, J.B., Fedorova, V.A., Ilyina, V.I., 1999. Jurassic and lowermost Cretaceous dinoflagellate cysts biostratigraphy of the Russian Platform and north Siberia, Russia. American Association of Stratigraphic Palynologists Contributions Series 36, 179 pp.

Riding, J.B., Mantle, D.J., Backhouse, J., 2010. A review of the chronostratigraphical ages of Middle to Late Jurassic dinoflagellate cyst biozones of the North West Shelf of Australia. Review of Palaeobotany and Palynology 162, 543-575.

Riding, J.B., Leng, M.J., Kender, S., Hesselbo, S.P., Feist-Burkhardt, S., 2013. Isotopic and palynological evidence for a new Early Jurassic environmental perturbation. Palaeogeography, Palaeoclimatology, Palaeoecology 374, 16-27.

Rita, P., Reolid, M., Duarte, L.V., 2016. Benthic foraminiferal assemblages record major environmental perturbations during the Late Pliensbachian-Early Toarcian 
interval in the Peniche GSSP, Portugal. Palaeogeography, Palaeoclimatology,

Palaeoecology 454, 267-281.

1142

Rocha, R.B., Mattioli, E., Duarte, L.V., Pittet, B., Elmi, S., Mouterde, R., Cabral, M.C.,

1144 Comas-Rengifo, M.J., Gómez, J.J., Goy, A., Hesselbo, S.P., Jenkyns, H.C., Littler, K.,

Mailliot, S., Oliveira, L.C.V., Osete, M.L., Perilli, N., Pinto, S., Ruget, C., Suan, G.,

2016. Toarcian Stage of Lower Jurassic defined by the Global Boundary Stratotype

Section and Point (GSSP) at the Peniche section (Portugal). Episodes 39, 460-481.

Silva, F., Duarte, L.V., Oliveira, L.C.V., Comas-Rengifo, M.J., Rodrigues, R., 2006.

Vale das Fontes Formation in the northern sector of the Lusitanian Basin (Portugal):

1151

Characterization and preliminary evaluation of the Total Organic Carbon. Actas do VII

Congresso Nacional de Geologia, Évora, 669-672.

Silva, R.L., Duarte, L.V., Comas-Rengifo, M.J., Mendonça Filho, J.G., Azerêdo, A.C.,

2011. Update of the carbon and oxygen isotopic records of the Early-Late

1156

Pliensbachian (Early Jurassic, $\sim 187 \mathrm{Ma}$ ): insights from the organic-rich hemipelagic series of the Lusitanian Basin (Portugal). Chemical Geology 283, 177-184.

Silva, R.L., Duarte, L. V., 2015. Organic matter production and preservation in the

Lusitanian Basin (Portugal) and Pliensbachian climatic hot snaps. Global and Planetary

Change 131, 24-34.

1162

Silva, R.L., Duarte, L.V., Comas-Rengifo, M.J., 2015. Carbon isotope

1164 chemostratigraphy of Lower Jurassic carbonate deposits, Lusitanian Basin (Portugal): 
1165

1166

1167

1168

1169

1170

1171

1172

1173

1174

1175

1176

1177

1178

1179

1180

1181

1182

1183

1184

1185

1186

1187

1188

1189

Implications and limitations to the application in sequence stratigraphic studies, in:

Ramkumar, M. (Ed.), Chemostratigraphy: concepts, techniques, and applications.

Elsevier, pp. 341-371.

Smelror, M., Århus, N., Meléndez, G.L.M., Lardies, M.D., 1991. A reconnaissance study of Bathonian to Oxfordian (Jurassic) dinoflagellates and acritarchs from the Zaragoza region (NE Spain) and Figueira da Foz (Portugal). Revista Española de Micropaleontología 23, 47-82.

Soares, A.F., Rocha, R.B., Elmi, S., Henriques, M.H., Mouterde, R., Almeras, Y., Ruget, C., Marques, J., Duarte, L.V., Carapito, C., Kullberg, J.C., 1993. Le sous-bassin nord lusitanien (Portugal) du Trias au Jurassique moyen: histoire d'un "rift avorté".

Comptes Rendus de l'Académie des Sciences de Paris 317, 1659-1666.

Srivastava, S.K., 1987. Jurassic spore-pollen assemblages from Normandy (France) and Germany. Geobios 20, 5-79.

Srivastava, S.K., 2011. Spore-pollen biostratigraphy of the English Jurassic.

Palaeontographica Abteilung B 285, 113-201.

Suan, G., Mattioli, E., Pittet, B., Mailliot, S., Lécuyer, C., 2008. Evidence for major environmental perturbation prior to and during the Toarcian (Early Jurassic) oceanic anoxic event from the Lusitanian Basin, Portugal. Paleoceanography 23, PA1202, http://dx.doi.org/10.1029/2007PA001459. 
Suan, G., Mattioli, E., Pittet, B., Lécuyer, C., Suchéras-Marx, B., Duarte, L.V.,

Philippe, M., Reggiani, L., Martineau, F., 2010. Secular environmental precursors to

Early Toarcian (Jurassic) extreme climate changes. Earth Planetary Science Letters 290, $448-458$.

Terrinha, P.A.G., Ribeiro, C., Kullberg, J.C., Lopes, C., Rocha, R.B., Ribeiro, A., 2002.

Compressive episodes and faunal isolation during rifting in the Algarve and Lusitanian Basins, southwest Iberia. Journal of Geology 110, 101-113.

Valensi, L., 1947. Note préliminaire à une étude des microfossiles des silex jurassiques de la région de Poitiers. Comptes rendus hebdomadaires des séances de l'Académie des sciences $225,816-818$.

1202

van de Schootbrugge, B., Bailey, T.R., Rosenthal, Y., Katz, M.E., Wright, J.D., Miller,

K.G., Feist-Burkhardt, S., Falkowski, P.G., 2005. Early Jurassic climate change and the radiation of organic-walled phytoplankton in the Tethys Ocean. Paleobiology 31, 7397.

1207

Van Erve, A., Mohr, B., 1988. Palynological investigations of the Late Jurassic microflora from the vertebrate locality Guimarota coal mine (Leiria, Central Portugal).

1210 Neues Jahrbuch für Geologie und Paläontologie Abhandlungen 4, 256-262.

Weiss, M., 1989. Die Sporenfloren aus Rät und Jura Südwest-Deutschlands und ihre 
1227

1228

Wiggan, N.J., Riding, J.B., Franz, M., 2017. Resolving the Middle Jurassic dinoflagellate radiation: The palynology of the Bajocian of Swabia, southwest

Germany. Review of Palaeobotany and Palynology 238, 55-87.

Williams, G.L., Fensome, R.A., MacRae, R.A., 2017. The Lentin and Williams index of fossil dinoflagellates 2017 edition. American Association of Stratigraphic Palynologists, Contributions Series 48, 1097 p.

Wilson, R.C.L., Hiscott, R.N., Willis, M.G., Gradstein, F.M., 1989. The Lusitanian Basin of west-central Portugal: Mesozoic and Tertiary tectonic, stratigraphic and subsidence history. AAPG Memoir 46, 341-362.

Wood, G.D., Gabriel, A.M., Lawson, J.C., 1996. Palynological techniques - processing and microscopy, in: Jansonius, J., McGregor, D.C., (Eds.), Palynology: Principles and Applications. American Association of Stratigraphic Palynologists Foundation, Dallas, 1, pp. 29-50.

Woollam, R., Riding, J.B., 1983. Dinoflagellate cyst zonation of the English Jurassic. Institute of Geological Sciences Report 83/2, 42 pp.

Wright, V.P., Wilson, R.C.L., 1984. A carbonate sub-marine fan sequence from the Jurassic of Portugal. Journal of Sedimentary Petrology 54, 394-412.

Ziaja, J., 2006. Lower Jurassic spores and pollen grains from Odrowaz, Mesozoic margin of the Holy Cross Mountains, Poland. Acta Palaeobotanica 46, 3-83. 


\section{Display material captions:}

1244 Fig. 1. The location and geological setting of the Lusitanian Basin of western Portugal, adapted from Duarte et al. (2010). The six successions studied herein are indicated by numbers 1 to 6 . Successions 1 and 2 are the sections at Maria Pares $\left(40^{\circ} 3^{\prime} 10^{\prime \prime} \mathrm{N} ; 8^{\circ} 27^{\prime}\right.$ $\left.25^{\prime \prime} \mathrm{W}\right)$ and Fonte Coberta (40 $\left.33^{\prime} 44^{\prime \prime} \mathrm{N} ; 8^{\circ} 27^{\prime} 31^{\prime \prime} \mathrm{W}\right)$ respectively; both are close to Rabaçal village. Sections 3 and 4 are Vale das Fontes $\left(40^{\circ} 12^{\prime} 10^{\prime \prime} \mathrm{N} ; 8^{\circ} 51^{\prime} 31^{\prime \prime} \mathrm{W}\right)$ and Brenha (40 $\left.11^{\prime} 49^{\prime \prime} \mathrm{N} ; 8^{\circ} 49^{\prime} 55^{\prime \prime} \mathrm{W}\right)$ respectively; both are located north of Figueira da Foz. The São Pedro de Moel composite section (Polvoeira section: $39^{\circ} 43^{\prime} 18^{\prime \prime} \mathrm{N}, 9^{\circ} 02^{\prime}$ $\left.56^{\prime \prime} \mathrm{W}\right)$ is near the village of São Pedro de Moel and is the section number 5. The Peniche section $\left(39^{\circ} 22^{\prime} 15^{\prime \prime} \mathrm{N} ; 9^{\circ} 23^{\prime} 07^{\prime \prime} \mathrm{W}\right)$ is number 6 , close to the town of Peniche.

Fig. 2. The ammonite biostratigraphy and lithostratigraphy of the Lower Jurassic (upper Sinemurian to upper Toarcian) of the eastern and western sectors of the Lusitanian Basin, central-western Portugal, based on Duarte and Soares (2002), Duarte (2007) and Duarte et al. (2014a, 2014b). The light grey shading indicates the lithostratigraphical units studied in the present work, and the dark grey shading indicates material studied by Correia et al. $(2017 a, b)$.

Fig. 3. The stratigraphical log of the upper Sinemurian succession in the São Pedro de Moel composite section (= the Polvoeira section of Duarte et al. $(2012,2014 a)$ ] adapted from Duarte et al. (2014a), with the positions of the palynomorph samples PM1 to PM12 indicated. No dinoflagellate cyst taxa were identified throughout this succession. 
1266 Fig. 4. The lithological log of the lower and upper Pliensbachian succession in the 1267 composite section at Brenha, adapted from Silva et al. (2006), with the positions of the palynomorph samples $\mathrm{Br} 1$ to $\mathrm{Br} 20$ indicated. The uppermost part of this section, the

1269 Lemede Formation (samples BrLem1 and BrLem2), was not described by Silva et al.

1270 (2006). The ammonite biozones are based on, and modified from, Mouterde et al.

1271 (1978) and Elmi et al. (1988).The dinoflagellate cyst occurrences are indicated by black 1272 dots

Fig. 5. The stratigraphical log of the lower and upper Pliensbachian succession in the Peniche section, adapted from Phelps (1985), Duarte et al. (2010), Silva et al. (2011), Bárron et al. (2013) and Comas-Rengifo et al. (2016), with the positions of the palynomorph samples P-34 to P-8 indicated. The dinoflagellate cyst occurrences are indicated by black dots.

Fig. 6. A simplified lithological log of the upper Pliensbachian succession in the Fonte Coberta section. The positions of the palynomorph samples FC1 to FC5 are indicated. The ammonite biozones are based on, and modified from, Mouterde et al. (1964-1965) and Paredes et al. (2016). The dinoflagellate cyst occurrences are indicated by black 1284 dots

Figs. 7. The lithological log of the middle Toarcian part of the São Gião Formation in 1287 the Maria Pares section, adapted from Duarte (1995), with the positions of the palynomorph samples PZ55 to PZ70 indicated. The ammonite biozones are based on, 1289 and modified from, Mouterde et al. (1964-1965) and Elmi et al. (1989). Standard bed 
numbers $52-59 \mathrm{~b}$ are given immediately to the left of the lithological ornament. The dinoflagellate cyst occurrences are indicated by black dots.

Fig. 8. The lithological log of the upper Toarcian part of the São Gião Formation in the Maria Pares section, adapted from Duarte (1995), with the positions of the palynomorph samples PZ71 to PZ81 indicated. The ammonite biozones are based on, and modified from, Mouterde et al. (1964-1965) and Elmi et al. (1989). MMLSB = Marls and Marly Limestones with Sponge Bioconstructions member. Standard bed numbers 60-69S are given immediately to the left of the lithological ornament. The dinoflagellate cyst occurrences are indicated by black dots.

Fig. 9. The lithological log of the upper Toarcian Póvoa da Lomba Formation in the Maria Pares section, adapted from Duarte (1995), with the positions of the palynomorph samples PZ82 to PZ89 indicated. The ammonite biozones are based on, and modified from, Mouterde et al. (1964-1965), Elmi et al. (1989) and Henriques (1992). MMLB = Marls and Marly Limestones with Brachiopods member. Standard bed numbers 70B1750 are given immediately to the left of the lithological ornament. The dinoflagellate cyst occurrences are indicated by black dots.

Fig. 10. Selected dinoflagellate cysts from the Pliensbachian and Toarcian strata of the Lusitanian Basin, west central Portugal. All the specimens are housed in the collections of LNEG (Portuguese Geological Survey), S. Mamede de Infesta, Portugal. The sample numbers, slide numbers and the England Finder coordinates are quoted; all the scale bars represent $20 \mu \mathrm{m}$. 
1314 1. Luehndea spinosa Morgenroth 1970. Fonte Coberta section, upper Pliensbachian 1315 (Emaciaticeras emaciatum ammonite Biozone), sample FC5, slide 1, L25/4. Ventral 1316 view, high focus.

1317 2. Luehndea spinosa Morgenroth 1970. Fonte Coberta section, upper Pliensbachian 1318 (Emaciaticeras emaciatum ammonite Biozone), sample FC3, slide 1, T32/1. Ventral 1319 view, high focus. Note the epicystal archaeopyle.

1320 3. Luehndea spinosa Morgenroth 1970. Peniche section, upper Pliensbachian 1321 (Amaltheus margaritatus ammonite Biozone), sample P-26, slide 1, M35/1.

1322 4. Nannoceratopsis sp. Peniche section, upper Pliensbachian (Amaltheus 1323 margaritatus ammonite Biozone), sample P-20, slide 1, T35/4. Left lateral view. Note 1324 the two antapical horns of almost equal length.

1325 5. Nannoceratopsis gracilis Alberti 1961. Brenha section, upper Pliensbachian 1326 (Amaltheus margaritatus-Emaciaticeras emaciatum ammonite biozones), sample 1327 BrLem1, slide 1, G34/1. Right lateral view. Note the dorsal horn, which is larger than 1328 the ventral horn.

1329 6. Nannoceratopsis senex van Helden 1977. Brenha section, upper Pliensbachian 1330 (Amaltheus margaritatus-Emaciaticeras emaciatum ammonite biozones), sample 1331 BrLem1, slide 1, K41/2. Left lateral view. Note the single (dorsal) antapical horn, the 1332 subpentagonal lateral outline and the somewhat asymmetrical shape.

$13337 . \quad$ Nannoceratopsis senex van Helden 1977. Fonte Coberta section, upper 1334 Pliensbachian (Emaciaticeras emaciatum ammonite Biozone), sample FC3, slide 1, 1335 L31/4. Left lateral view. Note the dorsal antapical horn and the subpentagonal lateral 1336 outline.

1337 8. Nannoceratopsis senex van Helden 1977. Brenha section, upper Pliensbachian 1338 (Amaltheus margaritatus ammonite Biozone), sample Br14, slide 1, G49/3. Left lateral 
view. Note the single antapical horn and the symmetrical and very rounded outline; the cingular archaeopyle is visible in the top right of the specimen.

9. Nannoceratopsis senex van Helden 1977. Peniche section, upper Pliensbachian (Amaltheus margaritatus ammonite Biozone), sample P-25, slide 1, O48/4. Right lateral view. Note the single antapical horn and the symmetrical lateral outline; the cingular archaeopyle is visible in the top left of the specimen.

10. Nannoceratopsis senex van Helden 1977. Maria Pares section, upper Toarcian (Dumortieria meneghinii ammonite Biozone), sample PZ82, slide 1, P41/3. Left lateral view. Note the single antapical horn and the asymmetrical lateral outline.

\section{Nannoceratopsis ambonis Drugg 1978. Maria Pares section, upper Toarcian} (Hammatoceras speciosum ammonite Biozone), sample PZ81, slide 1, U62/2. Left lateral view. Note the prominent dark sagittal rim.

12. Nannoceratopsis ambonis Drugg 1978. Maria Pares section, upper Toarcian (Hammatoceras speciosum ammonite Biozone), sample PZ81, slide 1, X63/1. Right lateral view. Note the prominent dark sagittal rim.

Fig. 11. Selected dinoflagellate cysts from the Pliensbachian and Toarcian strata of the Lusitanian Basin, west central Portugal. All the specimens are housed in the collections of LNEG (Portuguese Geological Survey), S. Mamede de Infesta, Portugal. The sample numbers, slide numbers and the England Finder coordinates are quoted; all the scale bars represent $20 \mu \mathrm{m}$.

1. Valvaeodinium sp. Maria Pares section, middle Toarcian (Hildoceras bifrons ammonite Biozone), sample PZ57, slide 1, Q27/3. Note the relatively sparse cover of short, capitate processes and the combination (apical/intercalary) archaeopyle. 

section, middle Toarcian (Hildoceras bifrons ammonite Biozone), sample PZ57, slide 1, R70/3. Note the covering of short distally-blunt processes. ammonite Biozone), sample PZ71, slide 1, M52/2. Note the apical archaeopyle with 1368 deep accessory archaeopyle sutures. Toarcian (Hammatoceras speciosum ammonite Biozone), sample PZ77, slide 1, C32. 4 - ventral view, high focus. 5 - ventral view, low focus illustrating the dorsal surface. Note the rounded, subhexagonal cyst outline and the infrareticulate wall sculpture which is coarser near the sutures. The distinctive, strongly curved sutures surrounding the sulcus are evident in 4 . In 5, the two plate $\left(2^{\prime \prime}\right.$ and $\left.3^{\prime \prime}\right)$ precingular archaeopyle, the large, middorsal 4 "' plate and the sutural crests are clearly visible.

6. Scriniocassis priscus (Gocht 1979) Below 1990. Maria Pares section, upper Toarcian (Hammatoceras speciosum ammonite Biozone), sample PZ79, slide 1, W43/2.

1378 Dorsal view, high focus. Note the two plate precingular archaeopyle and the sulcus.

1379 7. Mendicodinium microscabratum Bucefalo Palliani et al. 1997. Maria Pares section, upper Toarcian (Hammatoceras speciosum ammonite Biozone), sample PZ79, slide 1, G49/2. Ventral view; note the epicystal archaeopyle and the microscabrate 1382 autophragm.

1383 8. Mendicodinium sp. Maria Pares section, upper Toarcian (Hammatoceras speciosum ammonite Biozone), sample PZ80, slide 1, H47/2. Oblique left lateral view. 9. $\quad$ ?Maturodinium inornatum Morgenroth 1970. Maria Pares section, upper Toarcian (Hammatoceras speciosum ammonite Biozone), sample PZ77, slide 1, X52/1.

1387 Note the hypocystal tabulation and the faint cingulum. 
10. Mancodinium semitabulatum Morgenroth 1970. Maria Pares section, upper

1389

1390

1391

1392

1393

1394

1395

1396

1397

1398

1399

1400

1401

1402

1403

1404

1405

1406

1407

1408

1409

1410

1411

Toarcian (Dumortieria meneghinii ammonite Biozone), sample PZ82, slide 1, X54/3.

Note the well-preserved, partly separated, small epicystal plates which are involved in the formation of the 'disintegration' type archaeopyle, in which all the epicystal plates are individually lost.

11. Mancodinium semitabulatum Morgenroth 1970. Brenha section, upper Pliensbachian (Amaltheus margaritatus ammonite Biozone), sample $\mathrm{Br} 15$, slide 1, T47/4. Ventral view, high focus. Note the presence of some of the small, partially detatched precingular plates.

12. Mancodinium semitabulatum Morgenroth 1970. Peniche section, lower Pliensbachian (Prodactylioceras davoei ammonite Biozone), sample P-29, slide 1, O37/1. Ventral view, median focus. Note the anterior sulcal plate (the sulcal tongue).

Fig. 12. Selected aquatic and terrestrially-derived palynomorphs from the Sinemurian to Toarcian strata of the Lusitanian Basin, west central Portugal. All the specimens are housed in the collections of LNEG (Portuguese Geological Survey), S. Mamede de Infesta, Portugal. The sample numbers, slide numbers and the England Finder coordinates are quoted; all the scale bars represent $20 \mu \mathrm{m}$.

1. Micrhystridium sp. (acanthomorph acritarch). Peniche section, lower Pliensbachian (Tragophylloceras ibex ammonite Biozone), sample P-34, slide 1, R37. 2. Micrhystridium sp. (acanthomorph acritarch). Maria Pares section, upper Toarcian (Hammatoceras speciosum ammonite Biozone), sample PZ79, slide 1, G46/1. 3. Acanthomorph acritarch indeterminate. Maria Pares section, upper Toarcian (Dumortieria meneghinii ammonite Biozone), sample PZ82, slide 1, N30. 
1412 4. Tasmanites sp. (prasinophyte). São Pedro de Moel section, upper Sinemurian 1413 (Oxynoticeras oxynotum ammonite Biozone), sample PM2, slide 1, S33.

1414 5. Kekryphalospora distincta Fenton \& Riding 1987 (spore). Maria Pares section, 1415 upper Toarcian (Dumortieria meneghinii ammonite Biozone), sample PZ82, slide 2, $1416 \mathrm{C} 36 / 1$.

1417 6. Classopollis classoides (Pflug 1953) Pocock \& Jansonius 1961 (pollen). São 1418 Pedro de Moel section, upper Sinemurian (Oxynoticeras oxynotum ammonite Biozone), 1419 sample PM2, slide 1, Q36.

$14207 . \quad$ Cerebropollenites macroverrucosus (Thiergart 1949) Schulz 1967 (pollen).

1421 Brenha section, upper Pliensbachian (Amaltheus margaritatus ammonite Biozone), 1422 sample Br14, slide 1, E54.

$1423 \quad 8 . \quad$ Alisporites sp. (pollen). Brenha section, upper Pliensbachian (Amaltheus 1424 margaritatus ammonite Biozone), sample Br17, slide 1, V46/2.

1425 9. Exesipollenites sp. (pollen). Maria Pares section, middle Toarcian (Hildoceras 1426 bifrons ammonite Biozone), sample PZ57, slide 1, M35/2.

1427 10. Spheripollenites sp. (a tetrad of pollen grains). Maria Pares section, middle 1428 Toarcian (Hildoceras bifrons ammonite Biozone), sample PZ58, slide 1, L51/1.

1429 11. Callialasporites dampieri (Balme 1957) Dev 1961 (pollen). Maria Pares section, 1430 upper Toarcian (Hammatoceras speciosum ammonite Biozone), sample PZ81, slide 3, $1431 \mathrm{~K} 29 / 4$.

1432 12. Callialasporites turbatus (Balme 1957) Schulz 1967 (pollen). Maria Pares 1433 section, upper Toarcian (Hammatoceras speciosum ammonite Biozone), sample PZ81, 1434 slide 3, N54. 
Fig. 13. A composite dinoflagellate cyst range chart for the Lower Jurassic of the

1437

1438

\section{Online supplementary data:}

\section{Figures 1-5:}

Supplementary Fig. 1. The relative abundances, expressed as percentages, of the five main palynomorph groups recorded from the upper Sinemurian (Oxynoticeras oxynotum and Echioceras raricostatum ammonite biozones) succession of the São Pedro de Moel section (samples PM1 to PM12). Note the overwhelming dominance of pollen.

Supplementary Fig. 2. The relative abundances, expressed as percentages, of the six main palynomorph groups recorded from the Pliensbachian (Uptonia jamesoni to Emaciaticeras emaciatum ammonite biozones) succession of the Brenha section (samples Br1 to Br20 and BrLem1 and BrLem2). Note the overall dominance of pollen.

Supplementary Fig. 3. The relative abundances, expressed as percentages, of the six main palynomorph groups recorded from the Pliensbachian (Tragophylloceras ibex to Emaciaticeras emaciatum ammonite biozones) succession of the Peniche section (samples P-34 to P-10). Note the overwhelming dominance of gymnosperm pollen. 
1461 Supplementary Fig. 4. The relative abundances, expressed as percentages, of the six

1462

1463

1464

1465

1466

1467

1468

1469

1470

1471

1472

1473

1474

1475

1476

1477

1478

1479

1480

1481

1482

1483

1484

1485

main palynomorph groups recorded from the upper Pliensbachian (Amaltheus margaritatus and Emaciaticeras emaciatum ammonite biozones) succession of the Fonte Coberta section (samples FC1 to FC5). Note the dominance of dinoflagellate cysts and gymnosperm pollen.

Supplementary Fig. 5. The relative abundances, expressed as percentages, of the six main palynomorph groups recorded from the middle and upper Toarcian (Hildoceras bifrons to Pleydellia aalensis ammonite biozones) succession of the Maria Pares section (samples PZ56 to PZ88). Note the dominance of gymnosperm pollen and prasinophytes.

\section{Tables 1-5:}

Supplementary Table 1. The palynomorph assemblages from the upper Sinemurian succession of the São Pedro de Moel section (12 samples, numbered PM1 to PM12), subdivided into five groups. The numbers in the cells represent percentages of the specified taxon within the overall palynoflora; blank spaces indicate the absence of the respective form.

Supplementary Table 2. The palynomorph assemblages from the lower and upper Pliensbachian succession of the Brenha section (22 samples, numbered $\mathrm{Br} 1$ to $\mathrm{Br} 20$, BrLem1 and BrLem2), subdivided into six groups. The numbers in the cells represent percentages of the specified taxon within the overall palynoflora; blank spaces indicate the absence of the respective form. Sample Br6 proved palynologically barren. 
1487 Supplementary Table 3. The palynomorph assemblages from the lower Pliensbachian to lower Toarcian succession of the Peniche section (72 samples, numbered P-34 to P-1, and P1 to P38), subdivided into six groups. Note that the new material herein is represented by samples P-34 to P-8, and indicated by the light shading. Samples P-7 to P38 (no shading) were previously studied by Correia et al. (2017b). The numbers in the cells represent percentages of the specified taxon within the overall palynoflora; blank spaces indicate the absence of the respective form. The fourteen barren sample numbers are asterisked.

Supplementary Table 4. The palynomorph assemblages from the upper Pliensbachian succession of the Fonte Coberta section (five samples, numbered FC1 to FC5), subdivided into six groups. The numbers in the cells represent percentages of the specified taxon within the overall palynoflora; blank spaces indicate the absence of the respective form.

Supplementary Table 5. The palynomorph assemblages from the lower, middle and 1503 upper Toarcian succession of the Maria Pares section ( 89 samples, numbered PZ1 to PZ89), subdivided into six groups. Note that the new material herein is represented by samples PZ55 to PZ89, and indicated by the light shading. The underlying samples PZ1 to PZ54 (no shading) were previously studied by Correia et al. (2017a).The numbers in the cells represent percentages of the specified taxon within the overall palynoflora; blank spaces indicate the absence of the respective form. The five barren sample numbers are asterisked. 